\title{
Just Friends? Managers' Connections to Judges
}

August 7, 2021

\begin{abstract}
We study the impact of social connections between judges and executives on the outcomes of Securities Class Action Litigation (SCAL). Judges who share a social network with a firm's executives are more likely to dismiss lawsuits against the firm. These connected cases are also resolved much faster and settled for significantly lower amounts. The favorable outcomes cannot be explained by the lower severity of connected cases, or by court, judge, or firm characteristics. Our results are robust to using new judge appointments as a source of exogenous variation in "connectedness". The expectation of more favorable litigation outcomes has an ex ante effect on connected managers' disclosure decisions. Connected managers issue more voluntary forecasts that walk up prevailing earnings expectations, particularly over the long term and also those that walk them down over the short term. Our evidence indicates that social connections influence judge impartiality and meaningfully alter litigation outcomes, as well as managers' disclosure decisions.
\end{abstract}

Keywords: social connections; litigation; management forecasts

JEL Classification: G32, J33, J41 


\section{Introduction}

An impartial and effective judicial process is key to securing the trust of both external capital market participants such as investors and analysts, and also managers and directors. ${ }^{1}$ The ex post ability of shareholders to rely on the judicial process to launch securities classaction litigation acts as a powerful external governance force disciplining corporate disclosure, financial reporting and managers' actions. ${ }^{2}$ But what if judges, the primary actors of the judicial process meant to secure the trust of capital markets, are not always impartial? How would such compromised impartiality affect the outcomes of shareholder litigation alleging misleading disclosure, and would it change managers' ex ante disclosure strategies? Our goal in this paper is to examine one challenge to judge impartiality: judges' social connections to corporate executives. We study the impact of social connections between judges and executives on the outcomes of Securities Class Action Litigation (SCAL), and ex-ante adjustments by executives to firm disclosures based on anticipated judicial outcomes.

Our paper provides evidence that social connections between judges and executives and/or directors influence the judicial process. We find that judges who share a social network with a firm's executives or directors are more likely to dismiss class action lawsuits against the firm. Cases assigned to these socially connected judges are also resolved much faster and settled for significantly lower amounts. Furthermore, because these more favorable litigation outcomes reduce the expected costs of litigation, they have ex ante effects on managers' disclosure choices. In particular, our evidence indicates that connected managers display a greater willingness to issue more voluntary forecasts that walk up prevailing earnings expectations.

\footnotetext{
${ }^{1}$ See, for example, La Porta, Lopez-de-Silanes, Shleifer, and Vishny (1997, 1998 and 2002), Shleifer and Vishny (1997), Leuz, Nanda and Wysocki (2003), La Porta, Lopez-de-Silanes, Pop-Eleches, and Shleifer (2004), Lerner and Schoar (2005); Hail and Leuz (2006).

${ }^{2}$ See, for example, Skinner (1994), Skinner (1997), Field, Lowry and Shu (2005), Hopkins (2018), Huang, Roychowdhury and Sletten (2020).
} 
The literature has only recently begun to recognize that court and judge characteristics can affect litigation outcomes, which in turn, has implications for litigation risk and corporate decisions (Chang and Schoar 2013; Huang, Hui and Li 2019; Chow, Huang, Hui and Shevlin 2020; Franke, Huang and Li 2020; Iverson, Madson, Wang and Xu 2020). Accounting and finance research has thus far focused on the role of judge ideology and experience, but judges have been largely assumed to be free of biases driven by the identity of the plaintiffs and defendants. ${ }^{3}$ The Code of Conduct for United States judges explicitly forbids judges to allow social relationships, among others, to influence their conduct or judgment. ${ }^{4}$ This assumption of impartiality is particularly interesting in the light of abundant evidence on the influence of social connections on various facets of corporate activity and governance. In particular, there is accumulating evidence that social relationships bias business outcomes in settings where one would normally expect arms-length professional relationships. ${ }^{5}$

In the court rooms, applying the law impartially and professionally, in a manner that is free from personal biases, is crucial to a fair trial. Because judges are trained to appreciate the importance of impartiality, it is often presumed that they can eliminate the influence of personal biases from their decisions (Nugent 1994). Consequently, it is rare for judges to recuse themselves or be disqualified, and cases are generally decided by the originally assigned judge. ${ }^{6}$ While various types of biases may exist, we are interested in a particular form of favorable bias: one that may arise due to the judge's social connection to the defendant firm's executives or

\footnotetext{
${ }^{3}$ Both judge ideology and judge expertise differ from bias in that they reflect a certain policy preference or a certain approach respectively that is applied consistently across plaintiffs and defendants. Legal scholars refer to judicial biases as discriminating against/favoring plaintiffs or defendants with a certain set of characteristics i.e. gender, socio-economic class etc. (Nugent 1994; Harris and Sen 2019).

${ }^{4}$ See the following link for the Judicial Code of Conduct: https://www.uscourts.gov/judges-judgeships/codeconduct-united-statesjudges\#: : :text=A\%20judge\%20should\%20respect\%20and,and\%20impartiality $\% 20$ of $\% 20$ the $\% 20$ judiciary.\&tex $\mathrm{t}=\mathrm{A} \% 20$ judge\%20should\%20not\%20allow,influence\%20judicial\%20conduct\%20or\%20judgment.

${ }^{5}$ Cohen, Frazzini, Malloy (2008 and 2010), Hwang and Kim (2009), Engelberg, Gao and Parsons (2012), Duchin and Sosyura (2013), Ishii and Xuan (2014), Cooney, Madureira, Singh and Yang (2015), Guan, Su, Wu, and Yang (2016), He, Pittman, Rui and Wu (2017).

${ }^{6}$ See, for example, Nugent (1994), Frost (2005); Robertson (2018).
} 
directors and result in a more advantageous treatment of the firm in SCAL. Judges may not be conscious of such biases, but these biases could nevertheless result in uneven outcomes across defendants and impair the consistency of the judicial process.

It is extremely difficult to empirically identify all possible social connections in a large sample of judges and executives. However, judges' and the executives' biographies provide an avenue to determining potential social links created by attending the same institutions of higher education. Such educational links have been shown to create affinity across individuals, facilitating access to financial information and influencing corporate decisions and governance. ${ }^{7}$ Overlapping at the same undergraduate or post-graduate institution offers opportunities for personal and professional interactions which are often reinforced over subsequent years via participation in alumni networks, donation programs and sport events. However, direct relationships between judges and executives are not necessary for a favorable bias to arise. The principle of "homophily" implies individuals may be favorably predisposed towards those whom they share common characteristics or experiences with (McPherson, Smith-Lovin and Cook 2001). In the context of litigation, a common alma mater could lead to a more positive interpretation of events and others' actions and, result in more advantageous judgments.

To examine whether judges display favorable biases towards socially connected defendants, we begin by analyzing litigation outcomes. In a sample of SCAL lawsuits filed between 1996 and 2017, we test whether educational ties between the judge and the defendant firm's executives or directors are associated with (1) a faster resolution, (2) a greater likelihood

\footnotetext{
${ }^{7}$ See Cohen, et al. (2008) and (2010); Hwang and Kim (2009); Engelberg, et al. (2012); Dushin and Sosyura (2013); Ishii and Xuan (2014); Cooney, et al. (2015); Guan, et al. (2016); He, et al. (2017).
} 
the lawsuit is dismissed, or (3) a lower lawsuit payout. ${ }^{8}$ All these outcomes are desirable from the defendant's perspective as they ease the demands on executives' attention and time and reduce monetary and reputational consequences. Consistent with the existence of such biases, we find that cases with socially connected judges and senior officers are $30 \%$ more likely to be dismissed. Further, they are resolved significantly faster - the number of days cases are under consideration is lower by approximately $25 \%$. Finally, connected defendants experience lower monetary consequences. In our full sample of lawsuits, payouts are $44 \%$ lower for connected firms and, among settled lawsuits only, approximately $42 \%$ lower. These univariate differences are highly economically and statistically significant. As discussed below, subsequent multivariate tests imposing stringent controls confirm the statistical and economic significance of our results.

Our findings hold after controlling for numerous firm and state characteristics, as well as state of headquarters and industry-year fixed effects which capture potential variation in litigation risk within the industry over time. ${ }^{9}$ Moreover, case severity, measured using class period and stock returns around the lawsuit filing, is not significantly different for connected and non-connected firms. Nevertheless, we control for case severity using both these lawsuit characteristics in our tests of litigation outcomes. A potential concern may be that omitted court or judge characteristics are driving the results. Models with court (judge) fixed effects identify the effect of social connections on litigation outcomes using within-court (withinjudge) variation in connectedness, providing assurance that court (judge) characteristics are not

\footnotetext{
${ }^{8}$ We classify a judge and a defendant firm as socially connected when the judge overlapped at the same school at either undergraduate or post-graduate institution with at least one senior officer or director from that firm. In defining school ties we follow Cohen et al. (2008) and many subsequent papers that used this classification. In additional analysis, we find that our results are robust to an alternative measure of educational ties that requires overlap between the judge and at least one firm officer or director in the law school.

${ }^{9}$ Industry membership is an important determinant of litigation risk (Francis, Philbrick and Schipper 1994; Kim and Skinner 2012). Moreover, there are industry-specific temporal trends in reporting and disclosure which can lead to time-varying scrutiny from regulators and investors (Gleason, Jenkins and Johnson 2008; Xu, Najand, and Ziegenfuss 2006; Reppenhagen 2010). Industry-year fixed effects capture this variation in litigation in an industry over time.
} 
responsible for the defendant-friendly outcomes we observe. Our results are robust to the inclusion of court or judge fixed effects. ${ }^{10}$

Next, we provide some evidence on the causal nature of the link between social connections and litigation outcomes. We conduct an instrumental-variables analysis in which we rely on new judicial appointments as an instrument for changes in social connectedness. Federal judge appointees are selected by the President of the United States and almost always represent the presidential political party to assure similar policy preferences (Lyles 1997; Huang et al. 2019). As such, these appointments are likely exogenous with respect to the judge's educational connections to various executives and directors. Moreover, new judge appointments significantly affect a firm's educational connectedness to federal judges. Our results are robust to using these new appointments as an instrument: we find that stronger connections to district court judges lead to faster resolution of SCAL litigation, greater likelihood of dismissal and significantly lower payouts. ${ }^{11}$

Our next set of analyses examines whether connected executives who expect less severe consequences of class action litigation alleging misleading disclosures adjust their management forecast strategy accordingly. Studies point to litigation's "chilling effect" on voluntary disclosures, particularly walk-up long-term forecasts. This chilling effect arises because managers worry that even non-opportunistically erroneous walk-up forecasts that are ex post inaccurate may be viewed as opportunistic by potential litigants (Baginski, Hassell, and Kimbrough 2002; Rogers and Van Buskirk 2009; Huang et al. 2019). Our findings indicate that social connections between executives and district court judges reduce the expected costs of

\footnotetext{
${ }^{10}$ The single exception is when we include judge fixed effects settlement amounts among non-dismissed cases are lower for socially connected cases, but no longer statistically significant. Judge fixed effects require variation in connected status among settled cases for the same judge and that variation is unfortunately limited in a sample of 700 settled cases.

${ }^{11}$ We focus on judges at the district court of the firm's state of headquarters because $84 \%$ of SCAL lawsuits are ultimately litigated in that state (Hopkins 2018). While lawsuits can be filed in states other than the firm's headquarters, legal panels tend to consolidate them into the state with the easiest access to documents and witnesses i.e., a firm's headquarters (Cox, Thomas and Bai 2009; Hopkins 2018; Houston, Liu and Wei 2019).
} 
litigation. Thus, we expect such connections to generate the reverse of this "chilling effect". That is, we expect managers with social connections to judges increase the frequency of longterm walk-up forecasts, even though these forecasts may need to be walked down later over shorter horizons as managers receive more information.

We study the frequencies of (1) long-term walk-up forecasts, (2) long-term walk-down forecasts, (3) short-term walk-up forecasts, and (4) short-term walk-down forecasts. ${ }^{12}$ In addition to panel regressions, we estimate two models that attempt to address potential selection concerns: (1) two stage least squares regressions in which new judge appointments serve as an instrument, and (2) a differences-in-differences model in which the treatment arises from a firm's first judicial connection resulting from a new judge appointment. We find that social connections to judges motivate managers to increase the frequency of walk-up forecasts particularly over the long term, and in some specifications, also over the short term. We also find that social connections to newly appointed district court judges increase the frequency of short-term walk-down forecasts. Our results are robust to using propensity score matching, and to including firm fixed effects wherever applicable. The evidence collectively suggests that because of the lower perceived litigation costs, connected managers are more comfortable with walking up analysts' expectations even though it may sometimes be necessary to walk them down closer to the earnings announcements.

In additional analyses, we examine whether managers at connected firms exhibit a lower tendency to report or disclose opportunistically, which might partially explain why they experience more favorable litigation outcomes. We study whether firms with connected managers issue forecasts that are ex post less optimistic with respect to realized earnings and whether they experience a lower frequency of SEC enforcement actions and financial

\footnotetext{
${ }^{12}$ Any management forecast issued less than or equal to (more than) 90 days before the estimate period end date is classified as a short-horizon (long-horizon) forecast. Walk-up (walk-down) forecasts are those that exceed (fall below) the prevailing consensus analysts' earnings expectation.
} 
restatements. Using both panel regressions and instrumental variables, there is no evidence that firms that have managers with social connections to judges are significantly different from those that do not along any of those dimensions. Further, litigation likelihood, which is a comprehensive way of capturing misrepresentations as perceived by plaintiffs, is not affected by connections to judges either. Overall, our findings suggest that connected firms obtain more favorable litigation outcomes even though they are not any less likely to misreport or issue misleading disclosure.

Our evidence is relevant to the literatures on judicial impartiality, social connections and on the implications of litigation risk for managers' actions. By showing that social connections to the defendant firm's executives impair judges' impartiality, we point to an overlooked deficiency in the judicial system. In order to safeguard capital markets and facilitate investors' trust, a judicial system must treat all participants fairly, assigning similar consequences for similar actions regardless of the defendant's or plaintiff's identities and characteristics. Our findings suggest that judges find it difficult to maintain this impartiality in important respects, despite their training and despite incentives to uphold the reputation of the courts and their own.

The effect of social networks has been shown in a variety of corporate contexts with studies typically exploring one of two questions: (1) whether social connections facilitate informal information transfers (Cohen et al. 2008, 2010; Engelberg et al. 2012), or (2) whether social connections encourage an "exchange of favors" either internally within the firm (for example, between executives and boards of directors) or in a contractual relationship (for example between firm managers and auditors) (Hwang and Kim 2009; Guan et al. 2016; He et al. 2017). Our paper contributes to this literature by demonstrating the impact of social connections in a setting where there is no overt or direct information transfer between the connected parties (firm managers and judges), nor is there a contractual relationship. 
Finally, the literature on social networks has documented numerous ex post outcomes that result from connections (Cohen et al. 2008, 2010; Hwang and Kim 2009; Engelberg et al. 2012; Duchin and Sosyura 2013; Ishii and Xuan 2014; Guan et al. 2016; He et al. 2017). Social connections may, however, also lead managers to make ex ante adjustments to their actions. A growing literature studies how court and judge characteristics affect managerial choices that depend on expected litigation risk i.e., disclosure, financial reporting quality, tax planning and corporate bankruptcy (Bourveau, Lou and Wang, 2018; Huang et al. 2019; Chow et al. 2020; Franke et al. 2020; Iverson et al. 2020). We add to this literature and the literature on social networks by examining the ex ante adjustments that firm executives make to their disclosure choices when they are socially connected to district court judges.

\section{Related Literature and Hypotheses}

\subsection{Judges and their Biases}

Abundant law literature discusses the desirability, potential safeguards and challenges to judge impartiality. ${ }^{13}$ The attention devoted to impartiality is not surprising given that the Code of Conduct for United States judges explicitly states: "A judge should not allow family, social, political, financial, or other relationships to influence judicial conduct or judgment." That is because the principle of impartiality is considered crucial to the fundamental right of a fair trial. Legal scholars acknowledge that most judges claim to set aside personal biases when making decisions and assert their impartiality, but they also point out that judicial biases can be sub-conscious and judges have incentives to ex post rationalize biased courses of action (Nugent 1994; Robertson 2018). ${ }^{14}$

\footnotetext{
${ }^{13}$ For reviews of this literature, please see Nugent (1994), Harris and Sen (2019), Rachlinski and Wistrich (2018), and Robertson (2018).

${ }^{14}$ Bias is commonly defined in law as "mental attitude or disposition of the judge toward a party to the litigation, and not to any views that he may entertain regarding the subject matter involved" (Black's Law Dictionary 147, 5th ed. 1979). Nugent (1994) defines prejudice as "a preconceived and unreasonable judgment or opinion, usually an unfavorable one, marked by suspicion, fear, intolerance, or hatred".
} 
Empirical evidence exists that political ideology (i.e., partisanship) is an important determinant of how judges rule. However, there is also general agreement that ideology represents a set of policy preferences, rather than a bias towards/against a particular plaintiff or a defendant (Harris and Sen 2019). ${ }^{15}$ Political views are instrumental in federal judges being nominated and appointed in the first place, and they are expected to rely on these political views when ruling on specific cases. Evidence on whether judge's characteristics other than political ideology, such as the judge's gender or race, systematically affect how the judge rules is mixed and limited to certain types of cases (for example, a judge's gender may be a predictive factor in gender-related cases). In any case, judges' characteristics capture specific backgrounds and experiences, and hence it may not be accurate to designate them as biases. ${ }^{16}$ Our interest lies in judges' differential rulings based on defendants' personal characteristics or judges' relationships with these defendants, which would more identifiably constitute examples of biases. Political science literature finds evidence that rulings vary predictably based on certain characteristics of plaintiffs or defendants including race, gender, socio-economic status and even physical attractiveness (Stewart 1980; Zebrowitz and McDonald 1991; Abrams et al. 2012; Rachlinski and Wistrich 2018). Most directly relevant to our study is judges' tendency to grant more lenient treatment to defendants from the same state in civil and tort cases. This regional bias results in significantly higher monetary awards for an in-state plaintiff if the defendant is out of state instead of in-state (Nugent 1994; Helland and Tabarrock 2002; Rachlinski, Wistrich and Guthrie 2015).

In the context of SCAL, the evidence on judges' influence on firm-level outcomes concentrates on judges' ideology and their level of experience. For example, liberal (conservative) judge ideology is a strong predictor of more plaintiff-friendly (defendant-

\footnotetext{
${ }^{15}$ See, for example, Giles, Hettinger and Peppers 2001, Segal and Spaeth 2002, Ruger et al. 2004, Martin et al. 2004, Epstein, Landes and Posner 2013, Huang et al. 2019.

${ }^{16}$ See, for example, Harris and Sen 2019, and Rachlinski and Wistrich 2018.
} 
friendly) outcomes (Huang et al. 2019). Huang et al. (2019) rely on their evidence to propose judge ideology as a measure of litigation risk and show that both litigation likelihood and corporate disclosure vary predictably with judge ideology at the relevant circuit court. In a similar vein, Chow et al. (2020) show that managers engage in less aggressive tax planning with more liberal Circuit Court and Tax Court judges.

Apart from judge ideology, research in finance and accounting has also explored the effect of judge experience on corporate bankruptcy outcomes. Iverson et al. (2020) document that cases with less experienced judges spend significantly more time in bankruptcy and obtain lower creditor recovery rates. Some judges also appear to rule consistently more in favor of debtors while others in favor of creditors (Chang and Schoar 2013), which is consistent with judges' policy preferences influencing corporate outcomes.

Interestingly, most of the evidence on judicial biases arising from the identities and characteristics of the parties to the lawsuit comes from civil, criminal, labor and family law and we are not aware of any evidence of similar biases based on SCAL lawsuits. Social networks, which we examine in this study, involve a form of group membership, and may give rise to preferential treatment of corporate defendants who are perceived as "network members". The evidence of regional bias among judges in civil cases and torts suggests that social networks may matter in class action litigation against corporations as well. But this possibility remains unexplored in the literature.

\subsection{Social Connections}

Social connections, and educational connections in particular, have been shown to affect a variety of corporate activities and governance. One stream of literature examines the role that such connections play in facilitating informal information transfers. For example, social connections formed through educational ties have been shown to facilitate information 
flows from firm executives to mutual funds (Cohen et al. 2008) and financial analysts (Cohen et al. 2010; Fang and Huang 2017). Further, studies find that social connections influence information flow from firm executives to lenders (Engelberg et al. 2012), and across managers within firms in the context of internal capital markets (Duchin and Sosyura 2013).

A second stream of literature focuses on how social connections lead to quid pro quo between parties linked through contractual relationships. For example, evidence suggests that members of the board of directors socially connected to managers approve higher executive compensation with lower performance-sensitivity (Hwang and Kim 2009). Directors presumably gain in exchange by retaining their positions on the board. Similarly, auditors socially connected to either the CEO or members of the audit committee board tolerate more aggressive financial reporting by the firms they audit (Guan et al. 2016 and He et al. 2017, respectively). Both studies document that auditors receive greater fees for their connected audit engagements. Ishii and Xuan (2014) provide evidence of the quid pro quo phenomenon between socially connected acquirer managers and target board members. Cooney et al. (2015) provide similar evidence for socially connected executives at IPO underwriters and directors of the IPO-issuing firms. Overall, prior research shows how robust and pervasive the influence of social connections can be in a variety of corporate contexts, generally encompassing either information transfers or an exchange of favors in a contractual relationship.

Importantly, the literature on social connections primarily focuses on connections that arise from common educational backgrounds. Educational histories are observable not only for executives but also for a variety of other individuals (such as financial analysts, auditors, underwriters), and have been shown to create affinity across individuals. ${ }^{17}$ Overlapping at the same undergraduate or post-graduate institution offers opportunities for personal and

\footnotetext{
${ }^{17}$ All studies on social networks referenced in this section have used educational backgrounds to determine social ties. Many of them focus on educational ties exclusively but some supplement educational connections with common prior work experience at another firm. While shared prior employment is likely to be an important source of connections for managers, it is uncommon for federal judges to share work experience with executives.
} 
professional interactions which are often reinforced over subsequent years via participation in alumni networks, donation programs and sporting events. A personal relationship may not even be necessary to favor individuals with the same alma mater as people are more positively inclined towards those they share characteristics and/or backgrounds with (McPherson et al. 2001).

\subsection{Hypotheses}

In developing our hypotheses, we are motivated by the existing literatures on judicial biases and social connections. There certainly exist opportunities for judges' biases to influence their decisions. Few personal biases are observable to external parties, and to the extent some biases are subconscious, they may not be apparent to judges themselves. While judges can in principle recuse themselves, in practice, judge recusals are quite rare (Nugent 1994). If a judge does not recuse herself/himself, litigants can petition the court to disqualify the judge from the case. But this procedure is tedious and often ineffective as it places a very high burden of proof on the party looking to dismiss the judge (i.e., a "bias-in-fact" standard). ${ }^{18}$ Mere allegations of a possible bias are insufficient to disqualify a judge. The documented presence of judicial biases in alternative settings such as criminal, labor and family law, together with the pervasive evidence on social connections' ability to induce biased behavior in corporate settings jointly point to a credible hypothesis. Namely, social connections of judges and corporate executives favorably influence outcomes in securities class action lawsuits against U.S. corporations.

There are grounds to expect that the hypothesis above may not find support in the data. Judicial guidelines, and indeed the judicial oath, impose on judges the onus of acting

\footnotetext{
1828 U.S.C. $\$ 144$ regulates judge disqualifications. According to section 144 judges must be removed from the case when a party to the case "files a timely and sufficient affidavit that the judge before whom the matter is pending has a personal bias or prejudice either against him or in favor of any adverse party....". The evidence of bias against the judge must be "sufficient to support a conclusion that bias actually exists." Mere appearance of a bias does not suffice.
} 
impartially. In particular, judges are expected to be self-aware of possible sources of their own biases and to discipline themselves accordingly (Nugent 1994). It is thus possible that judges are particularly careful with class action lawsuits where they are socially connected to the executives at the defendant firm. Additionally, the literature has typically demonstrated the power of social connections, through either informal transfers of information or through an exchange of favors in a contractual setting. Judicial bias arising out of social connections does not fit conveniently under either channel. Judges are assigned to $10 \mathrm{~b}-5$ cases randomly, and thus firm executives and judges have no pre-existing relation pertaining to the lawsuit itself. It is possible that judges receive certain private benefits from being generous in their decisions when lawsuits involve corporate defendants they are connected to (such as greater social acceptability, etc.). But, such an exchange of favors would be implicit and unobservable, and in conflict with the spirit of impartiality expected of judges.

To pursue this question empirically, we examine the following litigation outcomes: dismissal likelihood, case duration until dismissal and/or settlement and lawsuit payout amounts. If defendant firms whose executives are socially connected to judges obtain more favorable litigation outcomes, they would be more likely to see the lawsuit dismissed, the duration of the lawsuit would likely be shorter, and the lawsuit payout amount lower. However, with factors both in favor and against observing more favorable SCAL outcomes for connected defendants, we state our first hypothesis in the null:

Hypothesis 1: The dismissal rate, settlement amount and number of days in Security Class Action Litigation are not significantly different for defendant firms whose executives are socially connected to the judge relative to those whose executives are not connected.

Our interest in securities class action litigation outcomes stems in part from their implications for firm disclosure. SCAL lawsuits are often triggered in the first place by 
suspicions and allegations of ex post overly optimistic or misleading disclosure (Skinner 1994, Rogers, Van Buskirk and Zechman 2011; Huang et al. 2020). While one effect of litigation has been to discipline managers' disclosures, studies have also pointed out that the threat of litigation risk can stifle disclosure (Baginski, Hassell, and Kimbrough 2002; Rogers and Van Buskirk 2009; Huang et al. 2019). In particular, there is evidence of litigation's "chilling effect", which refers to managers' incentives to reduce voluntary forecasts of future earnings, especially those that exceed current market expectations (that is, walk-ups). This occurs because managers are hesitant to issue walk-up forecasts that turn out to be erroneous and overly optimistic ex post and consequently attract class action lawsuits alleging willful attempts to mislead.

If our evidence indicates that social connections between executives and district court judges lead to less severe litigation outcomes, then connected managers should rationally anticipate a lower expected litigation cost to walking up market expectations of earnings. Lower expected litigation costs should in turn generate the reverse of the "chilling effect". Specifically, we would expect connected managers to increase the frequency of walk-up forecasts. Importantly, we expect this effect to dominate among management forecasts issued over the longer-term, when non-strategic and unintentional errors in forecasts are more likely. Since observing the increase in the frequency of long-term walk-up forecasts is conditional on social connections influencing judicial outcomes, we state our second hypothesis in the null format:

Hypothesis 2: Increases in social connections between executives and district court judges have no significant effect on the frequency of long-term walk-up management forecasts. 
In our empirical analysis, we examine the impact of social connections not just on longterm walk-up forecasts, but also on long-term walk-downs as well as both walk-up and walkdown forecasts over the short term.

\section{The Effect of Social Connections on Litigation Outcomes}

\subsection{Research Design - Litigation Outcome tests}

The following regression tests the influence of managers' social connections to federal judges on litigation outcomes:

$$
\text { LitigationOutcomes }_{i s t}=\beta_{0}+\beta_{1} \text { Connect }_{i s t}+\gamma^{\prime} X_{i s t}+\text { StateFE }+ \text { Industry } * \text { YearFE }+\varepsilon_{i s t}
$$

where $i$ indexes firms, $t$ indexes time and $\mathrm{s}$ indexes state of headquarter location, respectively. $X$ represents a vector of control variables, which we discuss in more detail below. Conditional on litigation, we examine three litigation outcomes: (1) the likelihood of case dismissal (Dismissal), (2) the duration of the trial (Trial Days), and (3) the payout from the lawsuit (Lawsuit Payout and SettleAmount). Dismissal is an indicator variable that equals one if the lawsuit ends in a dismissal, and zero otherwise. Trial Days is the natural logarithm of the number of days between the case filing date and the dismissal/settlement date. Lawsuit Payout is measured as the natural logarithm of one plus the lawsuit payout, where payout is equal to zero for dismissed cases and to the settlement amount for settled cases. We first estimate a specification which includes both settled and dismissed cases to avoid truncating the sample based on lawsuit outcome (i.e. whether the lawsuit was dismissed versus settled). We then repeat our analyses using a smaller sample of settled cases only, for which lawsuit payout is equal to the natural logarithm of the settlement amount paid by defendant firms (SettleAmount).

The primary explanatory variable of interest, Connect, is an indicator variable that equals one if the federal judge handling the lawsuit is connected with any executive or director of the defendant firm. Following prior studies that examine social connections (e.g. Cohen et 
al. 2008 and 2010; Fang and Huang, 2017), we focus on school ties between judges and corporate insiders. Specifically, we obtain educational information on judges from the Federal Judicial Center's Biographical Directory of Federal Judges, and on executives and directors from BoardEx. Our measure of connection identifies a judge as "connected" to a firm if the case-presiding judge and at least one of the executives and directors of the firm attended the same university and same school during overlapping periods. ${ }^{19}$ The coefficient $\beta_{1}$ in regression (1) provides an estimate of the effect of the judicial connections on various litigation outcomes.

We control for a set of variables that are known to affect litigation outcomes. Specifically, we control for ex ante litigation risk using the Kim and Skinner (2012) measure $(K S)$. We control for firm characteristics such as size (Size), capital structure (Leverage), return on assets (ROA) the incidence of a loss (Loss), and stock returns (Returns) (Lang and Lundholm, 1993; Kasznik and Lev, 1995; Miller, 2002; Chen, Matsumoto and Rajgopal, 2011). We further control for analyst following (Analyst) to account for the influence of external monitors on litigation outcomes. We control for severity of the underlying cases by the Class Period and market reactions upon the filing of the cases $(C A R)$. Class Period is the natural logarithm of one plus the period covered by the lawsuits. $C A R$ is the three-day cumulative abnormal returns surrounding the filing date of the respective securities class action lawsuit. We estimate benchmark model parameters over a 200-day window preceding the lawsuit (event days -210 to -11) using the CRSP value-weighted market index as the benchmark. To mitigate the concerns that the local economic conditions might affect litigation risk, we control for state economic growth (GDP Growth) and unemployment (Unemployment). We provide more details on these variables in Appendix A.

\footnotetext{
${ }^{19}$ Following Cohen et al. (2008), educational connection is based on attending an institution over an overlapping period and obtaining the same category degree from that institution. The degrees are grouped into six categories as follows: (i) business school (Master of Business Administration), (ii) medical school, (iii) general graduate (Master of Arts or Master of Science), (iv) Doctor of Philosophy, (v) law school, and (vi) general undergraduate. In an alternative specification, we require overlap in the law school of the common university attended by judges and executives, since judges necessarily attend law school. Our results are robust to this specification.
} 
In our baseline specification, we include fixed effects for the state of a firm's headquarters (State FE) to control for time-invariant state characteristics. ${ }^{20} \mathrm{We}$ include industry*year joint fixed effects (Industry*YearFE) to absorb any time-varying effects at the industry level, particularly any systematic and temporal variation induced by firms operating in more litigious industries. We cluster standard errors at firm level.

\subsection{Data and Sample - Litigation Outcome Tests}

To construct our sample of securities class action lawsuits, we employ procedures similar to those outlined in Choi and Prichard (2012) and Huang et al. (2019). In particular, our sample starts in 1996 after the enactment of Private Securities Litigation Reform Act (PSLRA). We start with all securities class action lawsuit filings available from the Stanford Securities Class Action Clearinghouse (SCAC) over the period of 1996 to 2017. We exclude lawsuits that are 1) unrelated to Rule 10b-5, 2) filed against non-US companies, 3) filed against non-publicly listed firms, 4) not matchable with Compustat/CRSP database, 5) without data to construct control variables. Our final sample consists of 1,756 lawsuits, across 1,425 unique firms.

Table 1 Panel A presents descriptive statistics for our litigation outcome sample. All continuous variables are winsorized at the top and bottom percentiles. Conditional on litigation, the mean value of dismissal is 0.500 , suggesting that $50 \%$ of securities lawsuits in our sample were ultimately dismissed. On average, it takes 1,097 days to settle or dismiss a lawsuit case during our sample period. The mean lawsuit payout is approximately USD 13.95 million. $^{21}$ Because the majority of lawsuits in our sample are dismissed rather than settled, the median

\footnotetext{
${ }^{20}$ Our empirical choice is similar to prior studies that examine litigation outcomes (e.g. Huang et al. 2019). In particular, we refrain from including firm fixed effects in this regression. This is because tests of litigation outcomes are conditional on the incidence of lawsuits, and firms experience lawsuits infrequently (often only once within our sample period). Firm fixed effects would result in identification based only on firms that experience multiple lawsuits during our sample period, effectively eliminating most firms from the analysis.

${ }^{21}$ There are 178 lawsuits which were settled, but we do not observe the settlement amounts from the court filings. These latter lawsuits are excluded from both the lawsuit-payouts sample and the settlement-amounts sample. Thus, the lawsuit-payouts sample includes two types of cases: (a) those that were dismissed and (b) those that are settled for known settlement amounts.
} 
payout is 0 . For the 700 settled cases with data available, settlement amounts paid by defendant firms are substantial, with a mean (median) of USD 39.29 (9.00) million. In subsequent multivariate tests, we address the significant skewness in payouts and settlement amounts by using natural logarithms of these variables. Summary statistics on all other control variables are consistent with prior studies (e.g. Huang et al. 2019). The mean (median) firm-year observation in our sample has leverage of $21.5 \%$ (15.5\%), ROA of $-5.9 \%$ (1.5\%), and marketadjusted returns of $8.7 \%(12.7 \%)$ in the prior year. Out of the 1,756 lawsuits, the presiding judge had a social connection with at least one executive or director in the firm in $6.3 \%$ of the cases. The filing of these cases was accompanied by negative market-adjusted returns of $-3.5 \%$ on average. The mean (median) class period spans 423 (296) days.

\subsection{Univariate Results on Litigation Outcomes}

Table 2 provides some preliminary insights into the differences in litigation outcomes based on whether judges and executives are socially connected. The table reports mean levels of various litigation outcomes as well as control variables for cases where judges and executives and directors are socially connected $($ Connect $=1)$ and for those where they are not $($ Connect $=0)$, and $\mathrm{p}$-values from t-tests of the mean differences. For variables that involve unscaled values such as trial days, lawsuit payouts, settlement amounts, class periods, size and analyst following, the univariate tests rely on logarithmic transformations due to the substantial skewness in the variables.

We find that connected cases exhibit significantly higher dismissal rates and lower days spent in trial. The economic magnitudes of these effects are quite large. Connections to the judge increase the likelihood of dismissal by $30 \%$ (from $49.1 \%$ for Connect $=0$ to $63.6 \%$ for Connect=1) and reduce the (logged) number of days until resolution, i.e., trial days, by 
approximately $25 \%$. Lawsuit payouts in connected cases are about $44 \%$ lower than in cases without connections, and settlement amounts are about $42 \%$ lower for connected cases. ${ }^{22}$

Interestingly, the univariate tests indicate that the differential outcomes for cases in which the judges have educational links to executives or directors are unlikely to be driven by differential severity of the underlying cases. Neither class period (Class Period) nor marketadjusted three-day returns centered on the filing of the lawsuit $(C A R)$ are significantly different for cases for which Connect takes the value of one from those where it is equal to zero. This lack of disparity in case severity is not surprising, since district court judges are usually randomly assigned to cases. This overall univariate evidence suggests that cases with socially connected judges experience more favorable outcomes even though the severity of connected and non-connected cases is similar.

Turning to firm characteristics, firm size is statistically the most significant difference between connected and non-connected cases. This is as expected since, among firms experiencing a lawsuit, those that are larger are more likely to have executives and directors connected with federal judges. Connected firms are also less likely to report losses. We find no other significant differences in means between the set of connected and non-connected cases.

Our preliminary evidence from the univariate tests is consistent with the interpretation that social connections between judges and firms influence the judicial process, resulting in more favorable litigation outcomes for connected firms.

\subsection{Multivariate Results on Litigation Outcomes}

Table 3 presents the results of our multivariate tests on how social connections affect corporate litigation outcomes. Columns (1) and (2) of Panel A show that the likelihood of case

\footnotetext{
${ }^{22}$ The percentage difference is computed from the difference in logged amounts as follows. For lawsuit payouts, the percentage difference is (EXP[0.566 - 1.153] -1)*100\%, or -44\% approximately. For settlement amounts, the percentage difference is (EXP[1.834-2.379] -1$) * 100 \%$, or $-42 \%$ approximately.
} 
dismissal is significantly higher for connected cases. The coefficient on Connect is positive and significant with p-values less than 0.05 in both the logit and the OLS specification. Column (3) shows that Trial Days, the number of days the case is under consideration, is significantly lower, implying shorter deliberation periods when managers are socially connected to judges. We also find that cases presided by connected judges have significantly lower lawsuit payouts (Column (4)). Even after restricting the sample to only settled cases with available settlement amounts, our tests indicate that social connections are accompanied by lower settlement amounts (Column (5)).

The signs of estimated coefficients on the control variables are intuitive and consistent with findings in prior studies (e.g. Kim and Skinner, 2012; Huang et al., 2019). For example, lawsuits against loss firms are less likely to be dismissed. Lawsuits involving larger firms take more trial days to deal with and conclude with larger lawsuit payouts. Finally, cases that involve more serious cases (measured with longer Class Period and lower CAR) are less likely to be dismissed, take longer to be resolved and have higher lawsuit payouts.

In summary, we find that judges who share a social connection with sued firms' executives or directors are more likely to dismiss class-action lawsuits against those firms. Cases assigned to these socially connected judges are also resolved faster and with much smaller payouts. These outcomes are clearly desirable from the defendant's perspective as they ease the demands on executives' attention and time and reduce monetary and reputational consequences.

\subsection{Court and Judge Characteristics - Litigation Outcome Tests}

While our findings hold after controlling for numerous firm and state characteristics, as well as state of headquarters and industry-year fixed effects, a potential concern with our results is that omitted court or judge characteristics might be driving our results. For example, some 
courts might use advanced case management techniques, employ experienced law clerks and judges, and have higher judicial expertise and/or greater administrative capacity and efficiency in handling corporate lawsuits. To address this concern, we further include court fixed effects to account for difference in the quality of courts. This test consists of a within-group analysis that relies on comparisons within a given state, industry and time period combination, and court. Results in Panel B of Table 3 shows that our inferences remain unchanged.

Panel $\mathrm{C}$ of Table 3 imposes controls for judge fixed effects. Models with judge fixed effects identify the effect of social connections on litigation outcomes using within-judge variation in connectedness across lawsuits. Thus, including judge fixed effects ensures that judge ideology or other judge characteristics are not responsible for the defendant-friendly outcomes we observe. However, these specifications are extremely demanding. For measuring coefficients, they not only require judges to handle more than one case within our sample, but also require them to handle at least one case against a connected defendant and at least one case against a non-connected defendant. Results in Panel $\mathrm{C}$ show that we continue to find a significantly higher dismissal rates, fewer trial days, and lower lawsuit payouts.

In the much smaller sample of settled lawsuits, we no longer see significantly lower settlement amounts for connected cases when we include judge fixed effects. There are two potential explanations for this lack of significant results. First, they could be attributable to the small number of judges who handle both connected and non-connected cases in our sample. ${ }^{23}$ Second, it is also possible that when judges handle both connected and unconnected cases that are eventually settled, they develop benchmarks and have access to direct comparisons of settlement amounts that restrict their personal biases. ${ }^{24}$

\footnotetext{
${ }^{23}$ In this subsample of lawsuits, there are only 13 judges who handled at least one connected and one nonconnected case.

${ }^{24}$ We find that settlement amounts, lawsuit payout and trial days are significantly lower and dismissal rates significantly higher when we control for specific judge characteristics: ideology, gender, race and experience instead of including judge fixed effects in the regressions.
} 


\subsection{Instrumental Variables (IV) Regressions - Litigation Outcome Tests}

In this section, we examine whether plausibly exogenous variation in social connections leads to more lenient litigation outcomes using instrumental-variables (IV) analysis. In these tests, new federal judicial appointments serve as the instrument for changes in social connectedness.

The selection and appointment of judges are rarely influenced by the state and local politics (Lyles, 1997). Lyles (1997) analyzes judicial appointments at federal district courts from 1960 to 1996 and concludes that the outcomes of presidential elections largely determine who occupies the federal bench. As such, these new appointments are likely exogenous with respect to the judge's pre-existing educational connections to various executives and directors and with respect to any particular lawsuit. Moreover, judges are typically randomly assigned to $10 \mathrm{~b}-5$ cases. Thus, the appointment of a judge connected to a firm increases that firm's possibility of being assigned a connected judge in the event of a lawsuit, therefore satisfying the relevance condition of the instrument. ${ }^{25}$

We estimate the following two-stage regression:

Connect $_{\text {ist }}=\beta_{0}+\beta_{1}$ Connect_Appointed $d_{\text {ist }}+\gamma^{\prime} X_{i s t}+$ StateFE + Industry $*$ YearFE $+\varepsilon_{i s t}$

LitigationOutcomes $_{i s t}=\beta_{0}+\beta_{1}$ Connect Pred $_{i s t}+\gamma^{\prime} X_{i s t}+$ StateFE + Industry $*$ YearFE $+\varepsilon_{i s t}$

where $i$ indexes firms, $t$ indexes time and $s$ indexes state of location, respectively. Connect is an indicator variable that equals one if the federal judge handling the lawsuit is connected with any executives or directors of the defendant firm. Regression (2a) serves as the first stage in

\footnotetext{
${ }^{25}$ We do not use director or executive departures as instruments because such departures might be driven by litigation or other firm characteristics (e.g., performance).
} 
which we instrument Connect with Connect_Appointed, an indicator variable equaling one if there is a newly appointed judge in year $t$ who attended the same school in overlapping periods with at least one director or executive and zero otherwise.

Regression (2b) is the second stage estimation at the lawsuits-level, where we regress various litigation outcomes on the predicted value of connection (Connect_Pred) from the first stage. In the sample used for litigation outcome tests, Connect_Pred has a mean, median and standard deviation of $0.058,0.055$, and 0.053 respectively. In regression (2b), we include the same set of control variables and fixed effects as in regression (1).

Column (1) of Table 4 reports the first-stage estimation results, and Columns (2) through (5) report the results for the second stage. These results are robust to using new appointments as an instrument: we find that stronger connections to district court judges result in significantly greater likelihood of dismissal of SCAL litigation, faster lawsuit resolution, and significantly lower payouts, as well as settlement amounts.

\section{The Effect of Social Connections on Management Forecasts}

\subsection{Research Design - Management Forecast Tests}

Our next set of analyses examines whether executives who are more socially connected to district court judges rationally expect less severe consequences from class action lawsuits and adjust their management forecast strategy accordingly. In particular, we study the impact of social connections between judges and executives on the frequencies of (1) long-term walkup forecasts, (2) long-term walk-down forecasts, (3) short-term walk-up forecasts, and (4) short-term walk-down forecasts.

We first examine the link between social connections to judges and management forecast frequencies using the following OLS regressions:

Freq_Forecast $_{i s t}=\beta_{0}+\beta_{1} \%$ Connect $_{i s t}+\gamma^{\prime} X_{i s t}+$ FirmFE + StateFE + Industry*YearFE $+\varepsilon_{i s t}$ 
Freq_Forecast $t_{\text {ist }}$ refers to the frequency of management forecasts partitioned on forecast horizon and the relation to market expectations. Prior literature shows that the effect of litigation risk on disclosure varies with two factors: the disclosure's horizon and whether the disclosure raises or lowers these expectations (Skinner 1994; Cheng and Lo 2006; Rogers and Van Buskirk 2009; Roychowdhury and Sletten 2012; Huang et al. 2019). For every year in our sample, we calculate the number of short-horizon (long-horizon) management earnings forecasts issued by each firm. Any management forecast issued less than or equal to (more than) 90 days before the estimate period end date is classified as a short-horizon (long-horizon) forecast. Forecasts that are greater than (lower than) the consensus EPS are referred to as walkup (walk-down) forecasts. Freq_Forecast $t_{\text {ist }}$ is consequently partitioned into the frequencies of long-term walk-up forecasts, long-term walk-down forecasts, short-term walk-up forecasts, and short-term walk-down forecasts, respectively denoted Freq_Long_Walk-up, Freq_Long_Walk-down, Freq_Short_Walk-up and Freq_Short_Walk-down. \%Connect is a firm-level measure, capturing the percentage of district court judges in the headquarter state of a listed firm who attended the same school with overlapping periods with at least one of the directors or executives of the firm. Since a district judge is randomly assigned to a case, \% Connect thus captures the ex ante probability of having a connected judge presiding over a case.

In addition to firm and state characteristics included in the vector of control variables in our litigation outcome tests, we also control for the firm issuing debt or equity (Financing) since it can alter disclosure strategies (Lang and Lundholm 2000; Lo 2014; Ertimur, Sletten and Sunder 2014). Following Huang et al. (2019), we additionally control for earnings decreases (EPS_Decrease), earnings per share change (EPS_Change), earnings to price ratio (EPS_Ratio), and past earnings guidance of the same type as the corresponding dependent 
variable $(\operatorname{Lag}(D V)) .{ }^{26}$ Unlike the litigation outcome sample, our management forecast sample features multiple firm-year observations and we are thus able to include firm fixed effects $($ FirmFE) in all tests of forecast frequency.

The relation between a firm's disclosure choices and the connectedness of its executives to judges is susceptible to selection bias. Hence, in addition to using OLS, we also estimate this relation using (1) two-stage least squares regressions, and (2) a differences-in-differences model. Our two-stage instrumental variables (IV) specification relies on new judge appointments as the instrument, similar to our analyses of litigation outcomes. Specifically, the IV regressions are estimated as follows:

$\%$ Connect $_{i s t}=\beta_{0}+\beta_{1} \%$ Connect_Appointed ist $_{\text {ist }}+\gamma^{\prime} X_{i s t}+$ FirmFE + StateFE +

$$
\text { Industry*YearFE }+\varepsilon_{i s t}
$$

Freq_Forecast $_{i s t}=\beta_{0}+\beta_{1} \%$ Connect_Pred ${ }_{i s t}+\gamma^{\prime} X_{i s t}+$ FirmFE + StateFE +

$$
\text { Industry*YearFE }+\varepsilon_{i s t}
$$

The structure for the two-stage regressions is similar to that we employ for the litigation outcome tests and discussed in Section 3.6. \%Connect_Appointed in regression (4a) is the number of newly appointed judges in year $t$ who attended the same school in overlapping periods with at least one director or executive, as a percentage of the number of district judges. \%Connect_Pred, the primary explanatory variable in the second stage, is the predicted value of a firm's connectedness to judges from the first stage. Freq_Forecast ist $_{\text {refers }}$ to the frequency of management forecasts partitioned on the horizon and the relation to market expectations.

\footnotetext{
${ }^{26}$ For example, in the regression with Freq_Long_Walk-up as the dependent variable, $\operatorname{Lag}(D V)$ represents the lagged frequency of issuance of long-horizon walk-up forecasts.
} 
Our differences-in-differences tests for a causal relation: do managers change their disclosure behavior when their connectedness to judges increases as a result of new judge appointments? Treated firms are those for whom judicial connections change after a new judge is appointed.

$$
\begin{aligned}
\text { Freq_MgtForecasts }_{i s t}= & \beta_{0}+\beta_{1} \text { Connect_Appointed }_{i s t} * \text { Post }+\beta_{2} \text { Post }+\gamma^{\prime} X_{i s t}+\text { FirmFE }+ \\
& \text { StateFE }+ \text { Industry } * \text { YearFE }+\varepsilon_{i s t}
\end{aligned}
$$

Connect_Appointed takes the value of one for treatment firms, i.e. firms that experience the appointment of a socially connected judge to the relevant district. We employ a stacked differences-in-differences structure and avoid multiple treatments for the same firm. Specifically, we focus on the first connected appointment for each firm within our sample, to ensure that the period before appointment is not affected by previous appointments. We examine the time period extending from three years before the appointment to three years following the appointment. We exclude the appointment year itself from the analysis to obtain a clean pre-event and post-event period. Post is an indicator variable equal to one in the year of the appointment and in subsequent years. Control firms are drawn from the same headquarter state and year as treated firms, and we additionally ensure that they do not receive any treatment during the six-year window. ${ }^{27}$ For each firm we require at least one observation in the pre- and post-appointment period to be included in the tests. Since the model includes firm fixed effects, the coefficient $\beta_{1}$ in Eq. (4c) captures the average within-firm change in forecast frequency around the new judge appointment that relies on comparisons within a given firm, industrytime period combination, as well as state.

\footnotetext{
${ }^{27}$ In the primary tests, control firms are chosen with replacement. In additional robustness tests, to ensure that the same year of the same firm does not serve as a control firm-year in the post-event window of one treated firm and in the pre-event window of another treated firm, we choose control firms without replacement. All our results are robust to this alternative method of selecting control firms.
} 


\subsection{Data and Sample - Management Forecast Tests}

Our sample of management forecasts begins in 1996 ensuring that our entire sample period follows the passage of the PSLRA act and that the availability of management forecasts in the IBES Guidance Detail file is more widespread (Chuk, Matsumoto and Miller, 2013). Since our objective is to examine various types of disclosure in any given year, both quarterly and annual management EPS forecasts are included in the sample. Following prior studies (e.g. Ajinkya, Bhojraj, and Sengupta 2005; Houston, Lev, and Tucker 2010; Kim, Su and Zhu 2017), we exclude management forecasts categorized as earnings "pre-announcements" (or earnings guidance issued between fiscal period end and the earnings announcement date for that period). ${ }^{28}$ Our final sample consists of 73,476 firm-year observations associated with 7,205 unique firms for which we have the required data for our analyses. Panel B of Table 1 provides descriptive statistics. Managers provide more short-term forecasts relative to long-term ones and are more likely to walk expectations down rather than walk them up. $12.7 \%$ of firm-years witness long-term walk-up forecasts, with the corresponding percentage being $15.2 \%$ for longterm walk-down forecasts. Similarly, over the short term, $13.4 \%$ of firm years exhibit walk-up forecasts while $19.2 \%$ exhibit walk-down forecasts. The average firm in our sample is connected to $4.8 \%$ of district judges.

\subsection{Results on Management Forecasts}

Table 5 presents results from the OLS, IV, and the differences-in-differences models of forecast frequency. Panel A focuses on the OLS analysis. We find preliminary evidence suggesting that firms whose executives and directors have stronger connections to district court judges issue more walk-ups of prevailing expectations over long horizons - the coefficient

\footnotetext{
${ }^{28}$ Our results are robust to including pre-announcements in the tests.
} 
on \%Connect is significant and positive in Column (1). Interestingly, the positive and statistically significant coefficient \%Connect in Column (4) implies that more connected firms also issue more short-term walk-downs. We find no significant associations between social connections to judges and long-term walk-downs or short-term walk-ups. Overall, the results are consistent with socially connected managers feeling more comfortable issuing forecasts with a positive outlook especially over longer horizons when perfect foresight is unattainable and the risk of being inaccurate is high. Ex post, some of these forecasts may require an adjustment if it becomes increasingly clear to managers that actual earnings are likely to be lower than initially anticipated, prompting them to issue more short-term walk-down forecasts.

Panel B of Table 5 presents results from the first stage of the IV estimation, while Panel C reports those from the second stage. Columns (1)-(4) of Panel B differ only with respect to the measurement of the $\operatorname{Lag}(D V)$ variable. ${ }^{29}$ As expected, across all first-stage estimations, we find that the appointment of connected judges significantly increases the social connections between firm executives and district court judges. The null hypothesis that the instrument is weak is rejected at the $1 \%$ level. The second-stage estimation results in Panel C indicate that social connections to newly appointed judges motivate managers to significantly increase the frequency of long-term walk-up forecasts (Column 1) but not long-term walkdown forecasts (Column 2). Further, social connections to district court judges significantly increase the frequency of short-term walk-down forecasts (Column 4) but there is no evidence of a significant increase in the frequency of short-term walk-up forecasts (Column 3). The results are thus consistent with those obtained from the OLS regressions and suggest that because of lower perceived expected costs of litigation, managers are more comfortable with

\footnotetext{
${ }^{29}$ Since each of these first stage regressions corresponds to a second stage regression with a different forecast type frequency as the dependent variable, $\operatorname{Lag}(D V)$ is adjusted accordingly to correspond to the lag of that dependent variable. For example, in Column (1) of Table 5, Panel B, Lag $(D V) \_S e c o n d$ Stage captures the prior frequency of long-term-walk up forecasts. Similarly, in Column (4), Lag (DV)_Second Stage captures the prior frequency of short-term walk-downs, etc.
} 
both walking up analysts' expectations over longer horizons and walking them down over shorter horizons closer to the earnings announcements.

Table 5, Panel D presents the results from the differences-in-differences estimation. The coefficients on Connect_Appointed $*$ Post are positive and significant for long-term walkup forecasts (Column 1) and short-term walk-down forecasts (Column 4), as was the case in our OLS and IV specifications. Similarly, there is no significant change in the frequency of long-term walk-downs (Column 2) and short-term walk-ups (Column 3).

We further test the validity of our maintained assumption that judicial appointments are responsible for causing differences between the disclosure choices of treated versus control firms in parallel-trends tests. To do so, we estimate a specification that is analogous to Eq. (4c), except that we replace the Post indicator with separate indicators for each of the two years preceding, and the three years following the new judge appointment: Before $(t=-2)$, Before $(t=-$ 1), Post ( $t=1), \operatorname{Post}(t=2)$ and $\operatorname{Post}(t=3)$. Table 6 represents the results of these tests. These tests are centered on the year that a judge connected to a treatment firm is appointed (i.e., year $t$ ), with year $t-3$ serving as the benchmark year in the tests. We find that for each type of forecast in the table, the differences-in-differences coefficient is indistinguishable from zero in the years prior to the appointment of a connected judge (i.e., years $t-2$ and $t-1$ ). Moreover, the differences-in-differences coefficients for long-term walk-up forecasts (Column 1) are statistically significant in two of three years following the appointment year (years $t+1$ and $t+3)$. Those for short-term walk-down forecasts (Column 4) are statistically significant in each of the years following the appointment year. Collectively, these results imply that the significant differences we observe in the frequency of long-term walk-up and short-term walkdown forecasts are not attributable to trending differences between treated and control firms 
predating judicial appointments. Rather the significant differences in the forecasts of treated versus control firms are robustly centered on the appointment of connected judges. ${ }^{30}$

Collectively, our results imply that connected managers adjust their forecasting behavior in expectation of experiencing more favorable outcomes in 10b-5 lawsuits under connected judges. In particular, they are more comfortable issuing disclosures that raise market expectations relative to non-connected managers.

\section{Additional Tests}

\subsection{Social Connections and Trial Days for Settled Lawsuits}

Our results indicate that social connections to judges can help firms obtain more favorable litigation outcomes. Arguably, the most favorable outcome from the defendant's point of view is a dismissal. Dismissals not only severely reduce monetary consequences and reputational damage but also tend to be reached faster than settlements, allowing executives to focus their attention on the firm. In this section we test whether the time savings we document, i.e., fewer trial days for firms with executives socially connected to the judge, result almost exclusively from greater likelihood that a connected judge dismisses the lawsuit, or extend to settled lawsuits as well.

When we partition our subsample of settled lawsuits based on the status of social connections to the judge (Connect=1 versus Connect=0), we find Trial Days are not significantly different across the two groups. In particular, median days to reach a settlement

\footnotetext{
${ }^{30}$ The mean lag between nomination and appointment is 112 days. Thus, on average, there is a full calendar quarter between the two events. In $16 \%$ of cases, nomination occurs in the fiscal year prior to the eventual appointment. To account for the possibility that managers adapt their disclosure strategy as soon as they expect their judicial connections to imminently increase because of nomination, we re-estimate the differences-indifferences specification centered on the Presidential nominations of judges that are eventually appointed to the bench, instead of their actual appointment. Treated firms in this case are those for whom anticipated judicial connections change once a new judge is nominated. Our inferences on the increase in long-term walk-up and short-term walk-down forecasts remain unchanged.
} 
for a connected defendant are 1,177 versus 1,295 for those that are not connected. ${ }^{31}$ While connected firms are more likely to see their lawsuits dismissed leading to significant time saving, there appears to be no time benefit conditional on a lawsuit settlement.

These results, in conjunction with those on dismissal likelihood and settlement amounts, suggest that connected firms enjoy a higher dismissal likelihood, spend the same number of days in court till settlement conditional on non-dismissal but even then, are eventually liable for lower settlement amounts. Further, to the extent that trial days are a proxy for the extent of alleged misrepresentation or the level of lawsuit complexity, it appears that settled lawsuits of connected firms are no less complicated, but nevertheless enjoy more favorable outcomes upon settlement.

\subsection{Do socially connected firms engage in less misconduct?}

A potential alternative explanation for our results is that socially connected firms engage in less severe misconduct, resulting in more lenient litigation outcomes for these firms. This seems unlikely given that measures of case severity (i.e. class period and returns upon lawsuit filing) are not significantly different for connected and not connected cases. Our tests using new judge appointments as instruments and various fixed effects structures diminish endogeneity concerns in general. Nevertheless, in this section we present additional analyses to examine whether more connected firms engage in less severe or less frequent misconduct.

The tests in this section rely on a variety of proxies to identify variation in the type of misconduct that would subject firms to SCAL litigation. First, if more connected firms engage in less (more) misconduct, we would expect SCAL litigation likelihood to be lower (higher) for firms with social connections to district court judges. Litigation likelihood captures various

\footnotetext{
${ }^{31}$ Mean Trial Days (raw) and Trial Days (natural logarithm) are also not significantly different for the group of connected and not connected defendants.
} 
types of misconduct, including misleading disclosure and financial reporting. ${ }^{32}$ Second, we investigate whether social connections to district court judges influence the frequency of ex post optimistic management forecasts as it is well documented that overly optimistic disclosure can be deemed misleading by investors and subject to litigation (Rogers et al. 2011; Huang et al. 2020). Finally, we examine whether incidences of financial misreporting (as measured using financial restatements, fraud, and SEC Enforcement Actions) vary with the firm's social connectedness to district court judges.

For these tests, we rely on OLS and IV models similar to those employed in the management forecast tests (Eq. (3), (4a) and (4b)). We use new judge appointments as instruments in the two-stage least squares regressions. Our results are consistent between the OLS and the IV models, and since the IV models are better suited to addressing endogeneity concerns, we tabulate this set of results in Table 7.

Panel A of Table 7 shows the first-stage results from regressing the percentage of judges socially connected to the firm on the instrument, control variables and fixed effects for firm, state and industry-year, for each of the dependent variables in the second stage. ${ }^{33}$ As expected, the appointment of a new connected judge has a strong positive impact on the percentage of judges connected to the firm. A Wald test rejects at $1 \%$ the hypothesis that the instruments have no effect on the endogenous variable. Panel B of Table 7 reports the second-stage estimations, in which we regress each dependent variable on the controls and the variation in the percentage

\footnotetext{
${ }^{32}$ The necessary assumption in using litigation likelihood as a proxy for misconduct is that investors do not condition their decision to file a lawsuit against a firm based on how connected its executives and directors are to district court judges. It seems unlikely that investors are aware of social links between firms and judges and choose not to pursue the case when they anticipate more favorable litigation outcomes for the defendants especially since judges are assigned randomly to each case. Nevertheless, if that were indeed the case, we would expect to find that stronger social connections lower litigation likelihood. A negative link between connections and litigation likelihood can thus result either from lower rates of misconduct for connected firms or from investors' expecting more lenient litigation outcomes for these firms. In contrast, a positive link between social connections and litigation likelihood would suggest that connected firms are emboldened by their connections and are more likely to engage in misconduct.

${ }^{33}$ While the instrument and control variables are identical to those used in our management forecast tests, $\operatorname{Lag}(D V) \_$Second Stage represents the lagged value of the corresponding dependent variable from the second stage regression.
} 
of connected judges predicted by the instruments. The dependent variables are respectively: $\operatorname{Pr}$ [Litigation] (column 1), Freq_Long_Optimistic (column 2), Freq_Short_Optimistic (column 3), and Misreporting (encompassing restatements, frauds and AAERs, column 4). None of the coefficients on \%Connect_Pred is statistically significant. Thus, we do not observe any evidence that financial misconduct is significantly different among firms with judicial connections relative to those without.

The lack of significant results in these tests is interesting on two counts. First, it indicates that firms with connected managers are no less likely to issue misleading disclosures or engage in misreporting, but nevertheless enjoy more favorable outcomes in litigation. Second, we do not find that socially connected firms are significantly more likely to issue misleading disclosures or misreport either, implying that social connections to judges do not necessarily encourage more opportunistic managerial behavior. Rather, they alter the managers' forecasting preferences and consequently the flow of information to capital markets.

\subsection{Propensity Score Matching}

In addition to relying on IV tests, to mitigate concerns that our results in part reflect inherent differences between treated and control firms, we also examine whether our results are robust to propensity score matching (PSM). For tests on litigation outcomes, the first stage of the PSM procedure models the connected status of a judge to the firm on a specific lawsuit (i.e., Connect) as a function of the control variables already introduced in Table 3, including firm characteristics and lawsuit severity. In the second stage we match each treatment firm to a control firm based on a caliper of 0.0005 in the first-stage probability estimate and re-estimate the regression in Table 3 on this PSM sample. Both first and second stages include state and industry-year fixed effects. These un-tabulated tests confirm that the results in Table 3 on 
higher dismissal likelihood, lower trial days, lower lawsuit payout and lower settlement amounts are robust to using the PSM sample.

For our tests on management forecasts, the first stage of the PSM models \%Connect, i.e., the firm's connectedness to district court judges as a function of all the control variables already introduced in Table 5, including multiple firm characteristics. Each treatment firm is then matched to a firm headquartered in the same state with the closest predicted \%Connect in the first stage. We do not include firm fixed effects in the first stage, as it results in nonconvergence, but do include state and industry-year fixed effects. The second stage includes firm, state and industry-year fixed effects. Un-tabulated tests indicate that our results on higher frequency of long-term walk-up forecasts and short-term walk-down forecasts for connected firms are robust to using the PSM sample. ${ }^{34}$

\section{Conclusion}

Our research examines whether social connections influence the outcomes of Security Class Action Litigation and whether these anticipated outcomes alter managers' disclosure choices. While social connections have been shown to matter in a variety of corporate contexts, their impact on SCAL litigation is far from obvious. The Code of Conduct for United States Judges explicitly forbids judges to allow social relationships to influence their conduct or judgment. Apart from the formal clauses, impartiality is generally considered critical to a wellfunctioning judicial system and held in high esteem by judges. Despite these expectations of impartiality, there is evidence in the political science and legal literature that judicial rulings exhibit evidence of biases based on the identity of plaintiffs and the defendants and judges' own relationships to these parties. In the context of business litigation and securities class action litigation, judicial characteristics such as expertise and political ideology have attracted

\footnotetext{
${ }^{34}$ All PSM tests results are available upon request.
} 
increasing attention from academics. However, the role of biases based on the identities of the litigating parties, in particular judges' connections to these parties, is largely unexplored. On the one hand, judges in securities class actions such as 10b-5 lawsuits are chosen at random, mitigating the possibility that a judge is connected to a specific defendant and/or the plaintiffs. On the other hand, the pervasiveness and impact of social connections based on educational ties has received increasing attention in the finance and economics literature, which raises the concern that judges' connections to corporate defendants may influence case outcomes.

In our empirical investigation, we find that cases assigned to judges with social connections to a defendant firm's executives are resolved on more defendant-friendly terms. First, such cases are $30 \%$ more likely to be dismissed than cases involving no social connections between presiding judges and the defendant firm's executives. This implies that defendants connected to judges can expect a quicker resolution and higher probability of avoiding monetary payouts. Second, even among settled cases, we find significantly lower settlement amounts among firms with judicial connections. These results are robust to a variety of specifications and econometric techniques that address potential selection concerns. Overall, our findings imply that social connections influence judge impartiality and result in different outcomes for similar misconduct.

Our paper also provides evidence that managers with social connections to judges rationally anticipate lower litigation costs and adapt their disclosure choices accordingly. They are more willing to walk up analysts' expectations, especially over the long term, and more likely to walk them down closer to earnings announcements. Interestingly, we find no evidence that firms with executives with more extensive connections to district court judges are more likely to mislead shareholders through their reporting and/or disclosure choices. Thus, we cannot discount the possibility that the greater leniency in judicial rulings when judges are connected to managers is beneficial for overall information flow to capital markets. More 
research is needed to draw conclusions about the overall desirability (or undesirability) of the judiciary's social connections to corporate executives, a question that offers scope for future exploration. 


\section{References}

ABRAMS DS; BERTRAND M; AND MULLAINATHAN S. "Do judges vary in their treatment of race?" Journal of Legal Studies 41(2012):347-83

AJINKYA, B.; S. BHOJRAJ; P. SENGUPTA. "The association between outside directors, institutional investors and the properties of management earnings forecasts." Journal of Accounting Research 43(2005): 343-376.

BAGINSKI, S. P.; J. M. HASSELL; AND M. D. KIMBROUGH. "The effect of legal environment on voluntary disclosure: Evidence from management earnings forecasts issued in US and Canadian markets." The Accounting Review 77(2002): 25-50.

BOURVEAU, T.; Y. LOU; AND R. WANG. "Shareholder litigation and corporate disclosure: Evidence from derivative lawsuits." Journal of Accounting Research 56(2018): 797-842.

CHANG, T., AND A. SCHOAR. "Judge specific differences in Chapter 11 and firm outcomes." Unpublished working paper, National Bureau of Economic Research Cambridge. 2013.

CHEN, S.; D. MATSUMOTO; AND S. RAJGOPAL. "Is silence golden? An empirical analysis of firms that stop giving quarterly earnings guidance." Journal of Accounting and Economics 51(2011): 134-150.

CHENG, Q., AND K. LO. "Insider trading and voluntary disclosures.” Journal of Accounting Research 44(2006): 815-848.

CHOI, S. J., AND A. C. PRITCHARD. "The supreme court's impact on securities class actions: An empirical assessment of Tellabs." The Journal of Law, Economics, and Organization 28(2012): 850-881.

CHOW, T.; A. HUANG; K. W. HUI; AND T. J. SHEVLIN. "Judge ideology and corporate tax planning." 2020 Available at SSRN 3513154.

COHEN, L.; A. FRAZZINI; AND C. MALLOY. "The small world of investing: Board connections and mutual fund returns." Journal of Political Economy 116(2008): 951-979.

COHEN, L.; A. FRAZZINI; AND C. MALLOY. "Sell-side school ties." The Journal of Finance 65(2010): 1409-1437.

COONEY JR, J. W.; L. MADUREIRA; A. K. SINGH; AND K. YANG. "Social ties and IPO outcomes." Journal of Corporate Finance 33(2015): 129-146.

COX, J. D.; R. S. THOMAS; AND L. BAI. "Do differences in pleading standards cause forum shopping in securities class actions: Doctrinal and empirical analyses." Wis. L. Rev., 2009: 421.

CHUK, E.; D. MATSUMOTO; AND G. S. MILLER. "Assessing methods of identifying management forecasts: CIG vs. researcher collected." Journal of Accounting and Economics 55(2013): 23-42.

DUCHIN, R., AND D. SOSYURA, D. "Divisional managers and internal capital markets." The Journal of Finance 68(2013): 387-429.

ENGELBERG, J.; P. GAO; AND C. A. PARSONS. "Friends with money." Journal of Financial Economics 103(2012): 169-188.

EPSTEIN, L.; W. M.LANDES; AND R. A. POSNER. "The behavior of federal judges." Harvard University Press. 2013.

ERTIMUR, Y.; E. SLETTEN; AND J. SUNDER. "Large shareholders and disclosure strategies: Evidence from IPO lockup expirations." Journal of Accounting and Economics 58(2014): 79-95.

FANG, L. H., AND S. HUANG. "Gender and connections among Wall Street analysts." The Review of Financial Studies 30(2017): 3305-3335.

FIELD, L.; M. LOWRY; AND S. SHU. "Does disclosure deter or trigger litigation?” Journal of Accounting and Economics 39(2005): 487-507. 
FRANCIS, J.; D. PHILBRICK; AND K. SCHIPPER. "Shareholder litigation and corporate disclosures." Journal of Accounting Research 32(1994): 137-164.

FRANKE, B.; A. HUANG; AND R. LI. "Securities Law Precedents, Litigation Risk, and Misreporting." 2020 Working Paper

FROST, A. "Keeping up appearances: process-oriented approach to judicial recusal". University of Kansas Law Review 53(2005), 531-594.

GILES, M. W.; V. A.HETTINGER; AND T. PEPPERS. "Picking federal judges: A note on policy and partisan selection agendas." Political Research Quarterly 54(2001): 623-641.

GLEASON, C. A.; N. T. JENKINS; AND W. B. JOHNSON. "The contagion effects of accounting restatements." The Accounting Review 83(2008): 83-110.

GUAN, Y.; L. N. SU; D. WU; AND Z. YANG. "Do school ties between auditors and client executives influence audit outcomes?" Journal of Accounting and Economics 61(2016): 506-525.

HAIL, L., AND C. LEUZ. "International differences in the cost of equity capital: Do legal institutions and securities regulation matter?" Journal of Accounting Research 44(2006): 485-531.

HARRIS, A. P., AND M. SEN. "Bias and judging." Annual Review of Political Science 22(2019): 241-259.

HE, X.; J. A.PITTMAN; O. M. RUI; AND D. WU. "Do social ties between external auditors and audit committee members affect audit quality?" The Accounting Review 92(2017): 61-87.

HELLAND, E., AND A. TABARROK. "The effect of electoral institutions on tort awards." American Law and Economics Review 4(2002): 341-370.

HOPKINS, J. "Do securities class actions deter misreporting?" Contemporary Accounting Research 35(2018): 2030-2057.

HOUSTON, J. F.; S, LIU AND L WEI. "Litigation risk and voluntary disclosure: evidence from legal changes." The Accounting Review 94(2019): 247-272.

HOUSTON, J. F.; B. LEV; AND J. W. TUCKER. "To guide or not to guide? Causes and consequences of stopping quarterly earnings guidance." Contemporary Accounting Research 27(2010): 143-185.

HUANG, A.; K. W. HUI; AND R. Z. LI. "Federal judge ideology: A new measure of ex ante litigation risk." Journal of Accounting Research 57(2019): 431-489.

HUANG, S.; S. ROYCHOWDHURY; AND E. SLETTEN. "Does litigation deter or encourage real earnings management?" The Accounting Review 95(2020): 251-278.

HWANG, B. H., AND S. KIM. "It pays to have friends." Journal of Financial Economics 93(2009): 138-158.

ISHII, J., AND Y. XUAN. "Acquirer-target social ties and merger outcomes." Journal of Financial Economics 112(2014): 344-363.

IVERSON, B.; J. MADSEN; W. WANG; AND Q. XU. "Financial costs of judicial inexperience." 2020. Working Paper.

KASZNIK, R., AND B. LEV. "To warn or not to warn: Management disclosures in the face of an earnings surprise." The Accounting Review 1995: 113-134.

KIM, I., AND D. J. SKINNER. "Measuring securities litigation risk." Journal of Accounting and Economics 53(2012): 290-310.

KIM, Y.; L. N. SU; AND X. K. ZHU. "Does the cessation of quarterly earnings guidance reduce investors' short-termism?." Review of Accounting Studies 22(2017): 715-752.

LANG, M., AND R. LUNDHOLM. "Cross-sectional determinants of analyst ratings of corporate disclosures.” Journal of Accounting Research 31(1993): 246-271. 
LANG, M. H., AND R. J. LUNDHOLM. "Voluntary disclosure and equity offerings: reducing information asymmetry or hyping the stock?" Contemporary Accounting Research 17(2000): 623-662.

LA PORTA, R.; F. LOPEZ-DE-SILANES; C. POP-ELECHES; AND A. SHLEIFER. “Judicial checks and balances." Journal of Political Economy 112(2004): 445-470.

LA PORTA, R.; F. LOPEZ-DE-SILANES; A. SHLEIFER; AND R. W. VISHNY. "Legal determinants of external finance." The Journal of Finance 52(1997): 1131-1150.

LA PORTA, R.; F. LOPEZ-DE-SILANES; A. SHLEIFER; AND R. W. VISHNY. "Law and finance." Journal of Political Economy 106(1998): 1113-1155.

LA PORTA, R.; F. LOPEZ-DE-SILANES; A. SHLEIFER; AND R. W. VISHNY. "Investor protection and corporate valuation." The Journal of Finance 57(2002): 1147-1170.

LERNER, J., AND A. SCHOAR. "Does legal enforcement affect financial transactions? The contractual channel in private equity." The Quarterly Journal of Economics 120(2005): 223-246.

LEUZ, C.; D. NANDA; AND P. D. WYSOCKI. "Earnings management and investor protection: an international comparison." Journal of Financial Economics 69(2003): 505527.

LO, A. K. "Do declines in bank health affect borrowers' voluntary disclosures? Evidence from international propagation of banking shocks." Journal of Accounting Research 52(2014): 541-581.

LYLES, K. L. "The gatekeepers: Federal district courts in the political process." Greenwood Publishing Group. 1997.

MARTIN, A; QUINN, K; RUGER, T; AND KIM, P. "Competing Approaches to Predicting Supreme Court Decision Making." Perspectives on Politics 2(2004):761-767.

MCPHERSON, M.; L. SMITH-LOVIN; AND J. M. COOK. "Birds of a feather: Homophily in social networks." Annual Review of Sociology 27(2001): 415-444.

MILLER, G. "Earnings performance and discretionary disclosure." Journal of Accounting Research 40(2002): 173-204.

NUGENT, D. C. "Judicial bias." Clev. St. L. Rev., 42(1994)

RACHLINSKI, J. J., AND A. J. WISTRICH. "Gains, Losses, and Judges: Framing and the Judiciary." Notre Dame L. Rev., 94(2018): 521.

RACHLINSKI, J. J.; A. J. WISTRICH; AND C. GUTHRIE. "Can judges make reliable numeric judgments: distorted damages and skewed sentences." Ind. LJ, 90(2015): 695.

REPPENHAGEN, D. A. "Contagion of accounting methods: Evidence from stock option expensing." Review of Accounting Studies 15(2010): 629-657.

ROBERTSON, C. "Judicial impartiality in partisan era." Florida Law Review 70 (2018), 739776.

ROGERS, J. L., AND A. VAN BUSKIRK. "Shareholder litigation and changes in disclosure behavior." Journal of Accounting and Economics 47(2009): 136-156.

ROGERS, J. L.; A. VAN BUSKIRK; AND S. L. ZECHMAN. "Disclosure tone and shareholder litigation." The Accounting Review 86(2011): 2155-2183.

ROYCHOWDHURY, S., AND E. SLETTEN. "Voluntary disclosure incentives and earnings informativeness." The Accounting Review 87(2012): 1679-1708.

RUGER, TW; KIM, PT; MARTIN, AD; AND QUINN, KM. "The Supreme Court forecasting project: legal and political science approaches to predicting Supreme Court decision making". Columbia Law Review 104(2004):1150-210

SEGAL, J. A., AND H. J. SPAETH. "The Supreme Court and the attitudinal model revisited." Cambridge University Press. 2002.

SHLEIFER, A., AND R. W. VISHNY. "A survey of corporate governance." The Journal of Finance 52(1997): 737-783. 
SKINNER, D. J. "Why firms voluntarily disclose bad news." Journal of Accounting Research 32(1994): 38-60.

SKINNER, D. J. "Earnings disclosures and stockholder lawsuits." Journal of Accounting and Economics 23(1997): 249-282.

STEWART, J. E. "Appearance and punishment: The attraction-leniency effect in the courtroom." The Journal of Social Psychology 125(1985): 373-378.

XU, T., NAJAND, M., AND ZIEGENFUSS, D. "Intra-industry effects of earnings restatements due to accounting irregularities". Journal of Business Finance and Accounting 33(2006), 696-714.

ZEBROWITZ, L. A., AND S. M. MCDONALD. "The impact of litigants' baby-facedness and attractiveness on adjudications in small claims courts." Law and human behavior 15(1991): 603-623. 
Appendix A Variables Definitions

\begin{tabular}{|c|c|}
\hline Variables & Definitions \\
\hline Litigation & $\begin{array}{l}\text { An indicator variable that equals one if the firm-year overlaps with the class period of } \\
\text { a securities class action lawsuit, and zero otherwise. We obtain data on securities class } \\
\text { action lawsuits from the SCAC's website. }\end{array}$ \\
\hline Dismissal & An indicator variable that equals one if lawsuit ends in a dismissal, and zero otherwise. \\
\hline Trial Days & $\begin{array}{l}\text { The natural logarithm of the number of days between the case filing date and the } \\
\text { dismissal/settlement date. }\end{array}$ \\
\hline Lawsuit Payout & $\begin{array}{l}\text { The natural logarithm of one plus the lawsuit payout, where payout is equal to zero } \\
\text { for dismissed cases and equal to the settlement amount for settled cases. }\end{array}$ \\
\hline SettleAmount & The natural logarithm of the settlement amount paid by defendant firms. \\
\hline Freq_Long_Walk-up & $\begin{array}{l}\text { The natural logarithm of one plus the number of long-horizon management earnings } \\
\text { forecasts with forecasted earnings greater than consensus analyst forecast. The long } \\
\text { horizon forecasts are those issued more than } 90 \text { days before the earnings } \\
\text { announcement. }\end{array}$ \\
\hline Freq_Long_Walk-down & $\begin{array}{l}\text { The natural logarithm of one plus the number of long-horizon management earnings } \\
\text { forecasts with forecasted earnings less than consensus analyst forecast. The long } \\
\text { horizon forecasts are those issued more than } 90 \text { days before the earnings } \\
\text { announcement. }\end{array}$ \\
\hline Freq_Short_Walk-up & $\begin{array}{l}\text { The natural logarithm of one plus the number of short-horizon management earnings } \\
\text { forecasts with forecasted earnings greater than consensus analyst forecast. The short } \\
\text { horizon forecasts are those issued within } 90 \text { days before the earnings announcement. }\end{array}$ \\
\hline Freq_Short_Walk-down & $\begin{array}{l}\text { The natural logarithm of one plus the number of short-horizon management earnings } \\
\text { forecasts with forecasted earnings less than consensus analyst forecast. The short } \\
\text { horizon forecasts are those issued within } 90 \text { days before the earnings announcement. }\end{array}$ \\
\hline Connect & $\begin{array}{l}\text { An indicator variable equal to one if the federal judge handling the lawsuit is } \\
\text { connected with any executive or director of the defendant firm, and zero otherwise. } \\
\text { We classify a judge and a defendant firm as socially connected when the judge } \\
\text { overlapped at the same school at either undergraduate or post-graduate institution with } \\
\text { at least one senior officer or director from that firm. }\end{array}$ \\
\hline$\%$ Connect & $\begin{array}{l}\text { The number of district court judges in the headquarter state of a listed firm that } \\
\text { attended the same school with overlapping periods with at least one of the directors } \\
\text { or executives, scaled by total number of district court judges in the headquarter state. }\end{array}$ \\
\hline Connect_Appointed & $\begin{array}{l}\text { An indicator variable that equals one if the firm experienced the appointment of a } \\
\text { socially connected judge in the headquarter state during the sample period, where a } \\
\text { socially connected judge is defined as at least one of the directors or executives } \\
\text { attended the same school with overlapping periods with the newly appointed district } \\
\text { court judge in year } t \text {, and zero otherwise. }\end{array}$ \\
\hline$\%$ Connect_Appointed & $\begin{array}{l}\text { The number of newly appointed judges in year t who attended the same school in } \\
\text { overlapping periods with at least one director or executive, scaled by the number of } \\
\text { district judges. }\end{array}$ \\
\hline $\begin{array}{l}\text { Connect_Pred, } \\
\% \text { Connect_Pred }\end{array}$ & $\begin{array}{l}\text { Predicted value of Connect and \%Connect from a first stage regression incorporating } \\
\text { Connect_Appointed and \%Connect_Appointed respectively as the corresponding } \\
\text { instruments. }\end{array}$ \\
\hline$K S$ & $\begin{array}{l}\text { Ex ante class action litigation risk at the beginning of year t, calculated using the } \\
\text { coefficient estimates from Model (3) in Kim and Skinner (2012). }\end{array}$ \\
\hline Size & The natural logarithm of market value of equity at the end of year $t-1$. \\
\hline Leverage & The ratio of total debt over total assets at the end of year $t-1$. \\
\hline$R O A$ & The operating income before depreciation scaled by total assets at the end of year $t-1$. \\
\hline Loss & $\begin{array}{l}\text { An indicator variable that equals one if the operating income before depreciation at } \\
\text { the end of year } t-1 \text { is negative and zero otherwise. }\end{array}$ \\
\hline Returns & The cumulative monthly value-weighted market returns in year $t-1$. \\
\hline Analyst & $\begin{array}{l}\text { The natural logarithm of one plus the number of unique analysts following a firm in a } \\
\text { fiscal year. }\end{array}$ \\
\hline
\end{tabular}




\section{Appendix A Variables Definitions, Continued}

\begin{tabular}{|l|l|}
\hline Class Period & The natural logarithm of one plus the period covered by the lawsuits. \\
\hline CAR & $\begin{array}{l}\text { The three-day cumulative abnormal returns surrounding the filing date of securities } \\
\text { class action lawsuits. We estimate benchmark model parameters over the 200-day } \\
\text { window (event days }-210 \text { to -11) using the CRSP value-weighted market index as the } \\
\text { benchmark }\end{array}$ \\
\hline EPS_Decrease & $\begin{array}{l}\text { An indicator variable that equals one if the firm's earnings per share in year } t \text { is lower } \\
\text { than that in year } \mathrm{t}-1 \text {, and } 0 \text { otherwise. }\end{array}$ \\
\hline EPS_Change & $\begin{array}{l}\text { The change in earnings per share from year } \mathrm{t}-1 \text { to year t, scaled by the stock price at } \\
\text { the end of year } \mathrm{t}-1 \text {. }\end{array}$ \\
\hline EPS_Ratio & The Earnings per share in year t, scaled by the stock price at the end of year t-1. \\
\hline Lag $(D V)$ & $\begin{array}{l}\text { Lagged dependent variable i.e. an indicator variable that equals one if the firm issued } \\
\text { corresponding management forecasts in lagged year and zero otherwise. }\end{array}$ \\
\hline GDP Growth & The percentage change in GDP of the firm's headquarter state from year t-1 to year t. \\
\hline Unemployment & The unemployment rate of the firm's headquarter state at the end of year t-1. \\
\hline Post & $\begin{array}{l}\text { An indicator variable that equals one for the years following a new judge appointment } \\
\text { in the headquarter state, and zero otherwise. }\end{array}$ \\
\hline Before $(t=-2)$ & $\begin{array}{l}\text { An indicator variable that equals one for year }-2 \text { relative to the year of a new judge } \\
\text { appointment in the headquarter state and zero otherwise. }\end{array}$ \\
\hline Before $(t=-1)$ & $\begin{array}{l}\text { An indicator variable that equals one for year }-3 \text { relative to the year of a new judge } \\
\text { appointment in the headquarter state and zero otherwise. }\end{array}$ \\
\hline Post $(t=1)$ & $\begin{array}{l}\text { An indicator variable that equals one for year }+1 \text { relative to the year of a new judge } \\
\text { appointment in the headquarter state and zero otherwise. }\end{array}$ \\
\hline Post $(t=2)$ & $\begin{array}{l}\text { An indicator variable that equals one for year }+2 \text { relative to the year of a new judge } \\
\text { appointment in the headquarter state and zero otherwise. }\end{array}$ \\
\hline Post $(t=3)$ & $\begin{array}{l}\text { An indicator variable that equals one for year }+3 \text { relative to the year of a new judge } \\
\text { appointment in the headquarter state and zero otherwise. }\end{array}$ \\
\hline
\end{tabular}




\section{Table 1 Summary Statistics}

Table 1 provides summary statistics for the variables used in litigation outcome tests (Panel A) and management forecast tests (Panel B). The sample period is from 1996 to 2017. All variables are defined in Appendix A.

\begin{tabular}{|c|c|c|c|c|c|c|}
\hline \multicolumn{7}{|c|}{ Panel A Summary Statistics for Litigation Outcomes Tests } \\
\hline & $\mathbf{N}$ & Mean & Std & $\mathbf{P 2 5}$ & Median & P75 \\
\hline Dismissal & 1,756 & 0.500 & 0.500 & 0.000 & 0.500 & 1.000 \\
\hline Trial Days(Raw) & 1,756 & 1097.000 & 821.100 & 502.500 & 883.000 & 1438.000 \\
\hline Lawsuit Payout (Raw, \$ millions) & 1,578 & 13.949 & 42.293 & 0.000 & 0.000 & 7.000 \\
\hline SettleAmount(Raw, \$ millions) & 700 & 39.290 & 99.350 & 3.850 & 9.000 & 24.000 \\
\hline Class Period (Raw) & 1,756 & 422.500 & 394.800 & 161.000 & 296.000 & 546.500 \\
\hline$C A R$ & 1,756 & -0.035 & 0.136 & -0.059 & -0.011 & 0.023 \\
\hline Connect & 1,756 & 0.063 & 0.242 & 0.000 & 0.000 & 0.000 \\
\hline$K S$ & 1,756 & 0.597 & 3.045 & -1.204 & -0.081 & 1.460 \\
\hline Size(Raw, \$ millions) & 1,756 & 8517.000 & 24411.000 & 338.000 & 1089.000 & 3854.000 \\
\hline Leverage & 1,756 & 0.215 & 0.229 & 0.005 & 0.155 & 0.350 \\
\hline$R O A$ & 1,756 & -0.059 & 0.268 & -0.075 & 0.015 & 0.068 \\
\hline Loss & 1,756 & 0.515 & 0.500 & 0.000 & 1.000 & 1.000 \\
\hline Analyst (Raw) & 1,756 & 11.070 & 10.800 & 1.000 & 8.000 & 17.000 \\
\hline Returns & 1,756 & 0.087 & 0.175 & -0.019 & 0.127 & 0.213 \\
\hline Unemployment & 1,756 & 0.058 & 0.018 & 0.047 & 0.054 & 0.064 \\
\hline GDP Growth & 1,756 & 0.045 & 0.028 & 0.029 & 0.043 & 0.063 \\
\hline \multicolumn{7}{|c|}{ Panel B Summary Statistics for Management Forecasts Tests } \\
\hline & $\mathbf{N}$ & Mean & Std & $\mathbf{P 2 5}$ & Median & P75 \\
\hline Freq_Long_Walk-up & 73,476 & 0.127 & 0.357 & 0.000 & 0.000 & 0.000 \\
\hline Freq_Long_Walk-down & 73,476 & 0.152 & 0.402 & 0.000 & 0.000 & 0.000 \\
\hline Freq_Short_Walk-up & 73,476 & 0.134 & 0.359 & 0.000 & 0.000 & 0.000 \\
\hline Freq_Short_Walk-down & 73,476 & 0.192 & 0.456 & 0.000 & 0.000 & 0.000 \\
\hline$\%$ Connect & 73,476 & 0.048 & 0.076 & 0.000 & 0.013 & 0.067 \\
\hline$K S$ & 73,476 & -0.960 & 2.320 & -2.396 & -1.401 & -0.106 \\
\hline Size(Raw, \$ millions) & 73,476 & 2625.10 & 6672.76 & 93.15 & 407.42 & 1669.23 \\
\hline Leverage & 73,476 & 0.225 & 0.246 & 0.022 & 0.167 & 0.351 \\
\hline$R O A$ & 73,476 & 0.039 & 0.306 & 0.019 & 0.091 & 0.154 \\
\hline Loss & 73,476 & 0.187 & 0.390 & 0.000 & 0.000 & 0.000 \\
\hline Analyst (Raw) & 73,476 & 7.00 & 8.93 & 0.00 & 4.00 & 11.00 \\
\hline Returns & 73,476 & 0.100 & 0.182 & -0.011 & 0.130 & 0.223 \\
\hline EPS_Decrease & 73,476 & 0.443 & 0.497 & 0.000 & 0.000 & 1.000 \\
\hline EPS_Change & 73,476 & 0.022 & 0.508 & -0.024 & 0.004 & 0.030 \\
\hline EPS_Ratio & 73,476 & -0.059 & 0.529 & -0.031 & 0.037 & 0.069 \\
\hline Lag_Freq_Long_Walk-up & 73,476 & 0.116 & 0.320 & 0.000 & 0.000 & 0.000 \\
\hline Lag_Freq_Long_Walk-down & 73,476 & 0.129 & 0.335 & 0.000 & 0.000 & 0.000 \\
\hline Lag_Freq_Short_Walk-up & 73,476 & 0.129 & 0.335 & 0.000 & 0.000 & 0.000 \\
\hline Lag_Freq_Short_Walk-down & 73,476 & 0.161 & 0.367 & 0.000 & 0.000 & 0.000 \\
\hline Unemployment & 73,476 & 0.059 & 0.019 & 0.046 & 0.054 & 0.068 \\
\hline GDP Growth & 73,476 & 0.045 & 0.028 & 0.030 & 0.045 & 0.063 \\
\hline
\end{tabular}




\section{Table 2 Univariate Analyses}

Table 2 presents two-sample T-tests of differences in means for the subsamples of lawsuits where Connect=1 versus Connect $=0$. The sample period is from 1996 to 2017. All variables are defined in Appendix A. ***, **, and $*$ denote statistical significance (two-sided) at the $1 \%, 5 \%$, and $10 \%$ levels, respectively.

\begin{tabular}{l|cccc}
\hline & Connect=1 & Connect=0 & p-value (diff.=0) & $* * *$ \\
\hline Dismissal & 0.636 & 0.491 & 0.00 & $* * *$ \\
Trial Days & 6.393 & 6.678 & 0.00 & $* * *$ \\
Lawsuit Payout & 0.566 & 1.153 & 0.00 & $*$ \\
SettleAmount & 1.834 & 2.379 & 0.06 & \\
Class Period & 5.599 & 5.599 & 0.99 & \\
CAR & -0.050 & -0.034 & 0.26 & \\
KS & 0.874 & 0.578 & 0.32 & $* * *$ \\
Size & 7.670 & 7.092 & 0.00 & \\
Leverage & 0.238 & 0.213 & 0.27 & \\
ROA & -0.039 & -0.060 & 0.44 & \\
Loss & 0.427 & 0.521 & 0.07 & \\
Analyst & 1.917 & 1.728 & 0.14 & \\
Returns & 0.089 & 0.086 & 0.87 & \\
Unemployment & 0.057 & 0.058 & 0.83 & \\
GDP Growth & 0.048 & 0.045 & 0.46 & \\
\hline
\end{tabular}




\section{Table 3 Litigation Outcomes}

Table 3 examines the association between connections and litigation outcomes. The sample period is from 1996 to 2017. Panel B and Panel C include the same set of control variables as in Panel A. All variables are defined in Appendix A. Intercepts are included but unreported. $t$-statistics are presented below the coefficients in parentheses. $* * *, * *$, and * denote statistical significance (two-sided) at the 1\%, 5\%, and $10 \%$ levels, respectively. Standard errors are corrected for heteroscedasticity and are clustered at the firm level.

\begin{tabular}{|c|c|c|c|c|c|}
\hline \multicolumn{6}{|c|}{ Panel A Litigation Outcomes } \\
\hline & (1) & (2) & (3) & (4) & (5) \\
\hline & Logit & OLS & OLS & OLS & OLS \\
\hline & Dismissal & Dismissal & Trial Days & Lawsuit Payout & SettleAmount \\
\hline \multirow[t]{2}{*}{ Connect } & 0.722 & 0.134 & -0.352 & -0.79 & -1.057 \\
\hline & $(2.46) * *$ & $(2.18) * *$ & $(-3.04)^{* * *}$ & $(-4.46) * * *$ & $(-2.56) * *$ \\
\hline \multirow[t]{2}{*}{$K S$} & -0.000 & 0.001 & 0.022 & -0.008 & 0.031 \\
\hline & $(-0.00)$ & $(0.12)$ & $(2.68)^{* * *}$ & $(-0.58)$ & $(1.06)$ \\
\hline \multirow[t]{2}{*}{ Size } & -0.095 & -0.015 & 0.083 & 0.212 & 0.519 \\
\hline & $(-2.35)^{* *}$ & $(-1.91)^{*}$ & $(5.85)^{* * *}$ & $(7.09) * * *$ & $(12.86) * * *$ \\
\hline \multirow[t]{2}{*}{ Leverage } & 0.223 & 0.028 & -0.195 & -0.050 & -0.568 \\
\hline & $(0.68)$ & $(0.41)$ & $(-1.49)$ & $(-0.24)$ & $(-1.67)^{*}$ \\
\hline \multirow[t]{2}{*}{$R O A$} & -0.444 & -0.082 & 0.120 & -0.032 & -0.444 \\
\hline & $(-1.64)$ & $(-1.42)$ & (1.19) & $(-0.18)$ & $(-1.93)^{*}$ \\
\hline \multirow[t]{2}{*}{ Loss } & -0.619 & -0.119 & 0.145 & 0.351 & 0.182 \\
\hline & $(-3.90) * * *$ & $(-3.70) * * *$ & $(2.50)^{* *}$ & $(3.37) * * *$ & $(1.25)$ \\
\hline \multirow[t]{2}{*}{ Analyst } & 0.133 & 0.024 & -0.024 & -0.045 & -0.030 \\
\hline & $(2.38) * *$ & $(2.11) * *$ & $(-1.26)$ & $(-1.07)$ & $(-0.52)$ \\
\hline \multirow[t]{2}{*}{ Returns } & 0.613 & 0.091 & 0.119 & 0.188 & -0.126 \\
\hline & $(0.75)$ & $(0.57)$ & $(0.47)$ & $(0.43)$ & $(-0.25)$ \\
\hline \multirow[t]{2}{*}{ Unemployment } & 3.163 & 0.884 & -1.353 & -4.873 & -7.440 \\
\hline & $(0.29)$ & $(0.40)$ & $(-0.36)$ & $(-0.71)$ & $(-0.70)$ \\
\hline \multirow[t]{2}{*}{ GDP Growth } & 0.403 & 0.140 & -0.863 & -0.553 & 0.197 \\
\hline & $(0.11)$ & $(0.18)$ & $(-0.66)$ & $(-0.22)$ & $(0.05)$ \\
\hline \multirow[t]{2}{*}{ Class Period } & -0.322 & -0.059 & 0.145 & 0.174 & 0.144 \\
\hline & $(-4.87)^{* * *}$ & $(-4.46) * * *$ & $(5.79) * * *$ & $(4.26)^{* * *}$ & $(2.25)^{* *}$ \\
\hline \multirow[t]{2}{*}{ CAR } & 1.845 & 0.305 & -0.248 & -1.422 & -0.958 \\
\hline & $(3.54) * * *$ & $(3.22)^{* * *}$ & $(-1.53)$ & $(-4.05) * * *$ & $(-2.17)^{* *}$ \\
\hline State FE & Yes & Yes & Yes & Yes & Yes \\
\hline Industry*Year FE & Yes & Yes & Yes & Yes & Yes \\
\hline Observations & 1,756 & 1,756 & 1,756 & 1,578 & 700 \\
\hline R-squared & 0.180 & 0.363 & 0.436 & 0.381 & 0.692 \\
\hline
\end{tabular}


Table 3 Litigation Outcomes, Continued

\begin{tabular}{|c|c|c|c|c|}
\hline \multicolumn{5}{|c|}{ Panel B Control for Court Fixed Effects } \\
\hline & $\begin{array}{c}\text { (1) } \\
\text { OLS } \\
\text { Dismissal }\end{array}$ & $\begin{array}{c}\text { (2) } \\
\text { OLS } \\
\text { Trial Days } \\
\end{array}$ & $\begin{array}{c}\text { (3) } \\
\text { OLS } \\
\text { Lawsuit Payout } \\
\end{array}$ & $\begin{array}{c}\text { (4) } \\
\text { OLS } \\
\text { SettleAmount } \\
\end{array}$ \\
\hline Connect & $\begin{array}{c}\mathbf{0 . 1 2 7} \\
(\mathbf{2 . 0 5})^{* *}\end{array}$ & $\begin{array}{c}-0.346 \\
(-2.98)^{* * *}\end{array}$ & $\begin{array}{c}-\mathbf{0 . 7 7 8} \\
(-4.27)^{* * *}\end{array}$ & $\begin{array}{c}-0.953 \\
(-1.97)^{* *}\end{array}$ \\
\hline $\begin{array}{l}\text { Controls } \\
\text { Court FE } \\
\text { State FE } \\
\text { Industry*Year FE } \\
\text { Observations } \\
\text { R-squared }\end{array}$ & $\begin{array}{c}\text { Yes } \\
\text { Yes } \\
\text { Yes } \\
\text { Yes } \\
1,756 \\
0.411\end{array}$ & $\begin{array}{c}\text { Yes } \\
\text { Yes } \\
\text { Yes } \\
\text { Yes } \\
1,756 \\
0.483\end{array}$ & $\begin{array}{c}\text { Yes } \\
\text { Yes } \\
\text { Yes } \\
\text { Yes } \\
1,578 \\
0.432 \\
\end{array}$ & $\begin{array}{l}\text { Yes } \\
\text { Yes } \\
\text { Yes } \\
\text { Yes } \\
700 \\
0.740\end{array}$ \\
\hline \multicolumn{5}{|c|}{ Panel C Control for Judge Fixed Effects } \\
\hline & $\begin{array}{c}(1) \\
\text { OLS } \\
\text { Dismissal }\end{array}$ & $\begin{array}{c}\text { (2) } \\
\text { OLS } \\
\text { Trial Days } \\
\end{array}$ & $\begin{array}{c}\text { (3) } \\
\text { OLS } \\
\text { Lawsuit Payout }\end{array}$ & $\begin{array}{c}\text { OLS } \\
\text { OettleAmount } \\
\end{array}$ \\
\hline Connect & $\begin{array}{c}0.222 \\
(2.28)^{* *}\end{array}$ & $\begin{array}{c}-0.429 \\
(-2.26)^{* *}\end{array}$ & $\begin{array}{c}-0.782 \\
(-1.83)^{*}\end{array}$ & $\begin{array}{l}\mathbf{0 . 0 0 1} \\
(\mathbf{0 . 0 0 )})\end{array}$ \\
\hline Controls & Yes & Yes & Yes & Yes \\
\hline Judge FE & Yes & Yes & Yes & Yes \\
\hline State FE & Yes & Yes & Yes & Yes \\
\hline Industry*Year FE & Yes & Yes & Yes & Yes \\
\hline Observations & 1,756 & 1,756 & 1,578 & 700 \\
\hline R-squared & 0.680 & 0.719 & 0.790 & 0.957 \\
\hline
\end{tabular}




\section{Table 4 Litigation Outcomes-Instrumental Variable Regression}

Table 4 examines the effect of connections on litigation outcomes using Instrumental Variable Regressions. The sample period is from 1996 to 2017. All variables are defined in Appendix A. Intercepts are included but unreported. $t$-statistics are presented below the coefficients in parentheses. $* * *, * *$, and * denote statistical significance (two-sided) at the 1\%, 5\%, and 10\% levels, respectively. Standard errors are corrected for heteroscedasticity and are clustered at the firm level.

\begin{tabular}{|c|c|c|c|c|c|}
\hline & $\begin{array}{c}(1) \\
\text { First Stage } \\
\text { Connect }\end{array}$ & $\begin{array}{c}\text { (2) } \\
\text { Dismissal } \\
\end{array}$ & $\begin{array}{c}\text { (3) } \\
\text { Trial Days }\end{array}$ & $\begin{array}{c}(4) \\
\text { Second Stage } \\
\text { Lawsuit Payout }\end{array}$ & $\begin{array}{c}\text { (5) } \\
\text { SettleAmount }\end{array}$ \\
\hline Connect_Pred & & $\begin{array}{c}\mathbf{0 . 5 1 1} \\
(3.71)^{* * * *}\end{array}$ & $\begin{array}{c}-0.896 \\
(-1.66) *\end{array}$ & $\begin{array}{c}-1.261 \\
(-3.09)^{* * * *}\end{array}$ & $\begin{array}{c}-2.225 \\
(-2.98)^{* * * *}\end{array}$ \\
\hline Connect_Appointed & $\begin{array}{c}0.981 \\
(20.03)^{* * *}\end{array}$ & & & & \\
\hline$K S$ & $\begin{array}{l}0.005 \\
(1.30)\end{array}$ & $\begin{array}{l}-0.001 \\
(-0.24)\end{array}$ & $\begin{array}{c}0.024 \\
(3.32)^{* * *}\end{array}$ & $\begin{array}{l}-0.006 \\
(-0.49)\end{array}$ & $\begin{array}{l}0.031 \\
(1.34)\end{array}$ \\
\hline Size & $\begin{array}{l}0.007 \\
(1.58)\end{array}$ & $\begin{array}{c}-0.018 \\
(-2.49)^{* *}\end{array}$ & $\begin{array}{c}0.086 \\
(6.67)^{* * *}\end{array}$ & $\begin{array}{c}0.213 \\
(8.35)^{* * *}\end{array}$ & $\begin{array}{c}0.527 \\
(17.15)^{* * *}\end{array}$ \\
\hline Leverage & $\begin{array}{l}0.022 \\
(0.71)\end{array}$ & $\begin{array}{l}0.023 \\
(0.38)\end{array}$ & $\begin{array}{l}-0.187 \\
(-1.64)\end{array}$ & $\begin{array}{l}-0.033 \\
(-0.19)\end{array}$ & $\begin{array}{c}-0.532 \\
(-2.04)^{* *}\end{array}$ \\
\hline$R O A$ & $\begin{array}{l}-0.028 \\
(-1.25)\end{array}$ & $\begin{array}{l}-0.068 \\
(-1.33)\end{array}$ & $\begin{array}{l}0.100 \\
(1.11)\end{array}$ & $\begin{array}{l}-0.053 \\
(-0.36)\end{array}$ & $\begin{array}{c}-0.470 \\
(-2.68) * * *\end{array}$ \\
\hline Loss & $\begin{array}{l}-0.021 \\
(-1.34)\end{array}$ & $\begin{array}{c}-0.112 \\
(-3.90) * * *\end{array}$ & $\begin{array}{c}0.134 \\
(2.62)^{* * *}\end{array}$ & $\begin{array}{c}0.338 \\
(3.76)^{* * *}\end{array}$ & $\begin{array}{l}0.170 \\
(1.55)\end{array}$ \\
\hline Analyst & $\begin{array}{l}0.002 \\
(0.37)\end{array}$ & $\begin{array}{c}0.023 \\
(2.31)^{* *}\end{array}$ & $\begin{array}{l}-0.023 \\
(-1.39)\end{array}$ & $\begin{array}{l}-0.045 \\
(-1.27)\end{array}$ & $\begin{array}{l}-0.045 \\
(-1.02)\end{array}$ \\
\hline Returns & $\begin{array}{l}0.030 \\
(0.43)\end{array}$ & $\begin{array}{l}0.074 \\
(0.53)\end{array}$ & $\begin{array}{l}0.142 \\
(0.63)\end{array}$ & $\begin{array}{l}0.197 \\
(0.53)\end{array}$ & $\begin{array}{l}-0.048 \\
(-0.12)\end{array}$ \\
\hline Unemployment & $\begin{array}{l}-0.299 \\
(-0.30)\end{array}$ & $\begin{array}{l}1.060 \\
(0.54)\end{array}$ & $\begin{array}{l}-1.607 \\
(-0.48)\end{array}$ & $\begin{array}{l}-5.516 \\
(-0.93)\end{array}$ & $\begin{array}{l}-8.474 \\
(-1.02)\end{array}$ \\
\hline GDP Growth & $\begin{array}{l}-0.097 \\
(-0.24)\end{array}$ & $\begin{array}{l}0.164 \\
(0.24)\end{array}$ & $\begin{array}{l}-0.898 \\
(-0.78)\end{array}$ & $\begin{array}{l}-0.527 \\
(-0.25)\end{array}$ & $\begin{array}{l}0.114 \\
(0.04)\end{array}$ \\
\hline Class Period & $\begin{array}{l}0.004 \\
(0.70)\end{array}$ & $\begin{array}{c}-0.061 \\
(-5.19) * * *\end{array}$ & $\begin{array}{c}0.148 \\
(6.72)^{* * *}\end{array}$ & $\begin{array}{c}0.180 \\
(5.06)^{* * *}\end{array}$ & $\begin{array}{c}0.146 \\
(2.95)^{* * *}\end{array}$ \\
\hline CAR & $\begin{array}{l}-0.031 \\
(-0.60)\end{array}$ & $\begin{array}{c}0.321 \\
(3.89)^{* * *}\end{array}$ & $\begin{array}{c}-0.270 \\
(-1.92)^{*}\end{array}$ & $\begin{array}{c}-1.433 \\
(-4.79)^{* * *}\end{array}$ & $\begin{array}{c}-0.981 \\
(-2.88)^{* * *}\end{array}$ \\
\hline State FE & Yes & Yes & Yes & Yes & Yes \\
\hline Industry*Year FE & Yes & Yes & Yes & Yes & Yes \\
\hline Observations & 1,756 & 1,756 & 1,756 & 1,578 & 700 \\
\hline R-squared & 0.323 & 0.339 & 0.422 & 0.377 & 0.680 \\
\hline
\end{tabular}




\section{Table 5 Management Forecasts}

This table estimates the effect of connections on the frequency of four different management forecast types. The sample period is from 1996 to 2017 . All variables are defined in Appendix A. Intercepts are included but unreported. $t$-statistics are presented below the coefficients in parentheses. $* * *, * *$, and $*$ denote statistical significance (two-sided) at the $1 \%, 5 \%$, and $10 \%$ levels, respectively. Standard errors are corrected for heteroscedasticity and are clustered at the firm level.

Panel A Management Forecasts-OLS

(1) (2) (3)

Freq_Long_Walk-up Freq_Long_Walk-down Freq_Short_Walk-up Freq_Short_Walk-down

\begin{tabular}{|c|c|c|c|c|}
\hline \%Connect & $\begin{array}{c}0.064 \\
(1.69)^{*}\end{array}$ & $\begin{array}{l}-0.020 \\
(-0.46)\end{array}$ & $\begin{array}{l}0.061 \\
(1.56)\end{array}$ & $\begin{array}{c}0.084 \\
(1.98)^{* *}\end{array}$ \\
\hline \multirow[t]{2}{*}{$K S$} & -0.001 & -0.002 & -0.002 & -0.003 \\
\hline & $(-2.03) * *$ & $(-4.07) * * *$ & $(-3.73)^{* * *}$ & $(-4.35)^{* * *}$ \\
\hline \multirow[t]{2}{*}{ Size } & 0.015 & 0.036 & 0.010 & 0.046 \\
\hline & $(7.35) * * *$ & $(15.28)^{* * *}$ & $(5.10) * * *$ & $(17.02)^{* * *}$ \\
\hline \multirow[t]{2}{*}{ Leverage } & 0.021 & 0.022 & 0.007 & 0.023 \\
\hline & $(2.88) * * *$ & $(2.85)^{* * *}$ & $(0.91)$ & $(2.70) * * *$ \\
\hline \multirow{2}{*}{$R O A$} & 0.007 & 0.002 & 0.005 & 0.002 \\
\hline & $(2.62)^{* * *}$ & $(0.93)$ & (1.61) & $(0.40)$ \\
\hline \multirow[t]{2}{*}{ Loss } & -0.032 & -0.021 & -0.036 & -0.025 \\
\hline & $(-9.94) * * *$ & $(-6.20) * * *$ & $(-10.78)^{* * *}$ & $(-5.81)^{* * *}$ \\
\hline \multirow[t]{2}{*}{ Analyst } & 0.013 & 0.013 & 0.010 & 0.017 \\
\hline & $(5.02) * * *$ & $(4.40)^{* * *}$ & $(3.64) * * *$ & $(5.08) * * *$ \\
\hline \multirow[t]{2}{*}{ Returns } & 0.013 & 0.030 & 0.001 & -0.021 \\
\hline & $(1.17)$ & $(2.59)^{* * *}$ & $(0.12)$ & $(-1.58)$ \\
\hline \multirow{2}{*}{ Financing } & 0.007 & -0.001 & 0.008 & -0.004 \\
\hline & $(1.31)$ & $(-0.20)$ & $(1.92)^{*}$ & $(-0.74)$ \\
\hline \multirow[t]{2}{*}{ EPS_Decrease } & -0.018 & 0.015 & -0.029 & 0.024 \\
\hline & $(-7.50)^{* * *}$ & $(5.99)^{* * *}$ & $(-11.57)^{* * *}$ & $(8.33)^{* * *}$ \\
\hline \multirow[t]{2}{*}{ EPS_Change } & -0.008 & 0.007 & -0.008 & 0.006 \\
\hline & $(-4.51) * * *$ & $(4.08)^{* * *}$ & $(-4.57) * * *$ & $(2.79) * * *$ \\
\hline \multirow[t]{2}{*}{ EPS_Ratio } & 0.003 & -0.010 & 0.005 & -0.008 \\
\hline & (1.49) & $(-4.81)^{* * *}$ & $(2.51)^{* *}$ & $(-3.46) * * *$ \\
\hline \multirow{2}{*}{$\operatorname{Lag}(D V)$} & 0.317 & 0.420 & 0.246 & 0.394 \\
\hline & $(36.12)^{* * *}$ & $(44.54)^{* * *}$ & $(30.52)^{* * *}$ & $(39.89) * * *$ \\
\hline \multirow[t]{2}{*}{ Unemployment } & 0.299 & 0.505 & 0.412 & 0.936 \\
\hline & (1.57) & $(2.56)^{* *}$ & $(2.16)^{* *}$ & $(4.20)^{* * *}$ \\
\hline \multirow[t]{2}{*}{ GDP Growth } & 0.123 & -0.009 & 0.057 & 0.110 \\
\hline & $(1.94)^{*}$ & $(-0.15)$ & $(0.98)$ & $(1.60)$ \\
\hline Firm FE & Yes & Yes & Yes & Yes \\
\hline State FE & Yes & Yes & Yes & Yes \\
\hline Industry*Year FE & Yes & Yes & Yes & Yes \\
\hline Observations & 73,476 & 73,476 & 73,476 & 73,476 \\
\hline R-squared & 0.499 & 0.583 & 0.484 & 0.588 \\
\hline
\end{tabular}


Table 5 Management Forecasts, Continued

Panel B Management Forecasts-IV First Stage

(3)

\%Connect (for Freq_Long_Walk-up) \%Connect (for Freq_Long_Walk-down)％Connect (for Freq_Short_Walk-up)

$\%$ Connect

\begin{tabular}{|c|c|c|c|c|}
\hline & \%Connect (for Freq_Long_Walk-up) & \%Connect (for Freq_Long_Walk-down) & \%Connect (for Freq_Short_Walk-up) & \%Connect (for Freq_Short_Walk-down) \\
\hline \%Connect_Appointed & $\begin{array}{c}0.725 \\
(30.40)^{* * *}\end{array}$ & $\begin{array}{c}0.725 \\
(30.37)^{* * *}\end{array}$ & $\begin{array}{c}0.725 \\
(30.41)^{* * *}\end{array}$ & $\begin{array}{c}0.725 \\
(\mathbf{3 0 . 3 6})^{* * *}\end{array}$ \\
\hline Controls & Yes & Yes & Yes & Yes \\
\hline Firm FE & Yes & Yes & Yes & Yes \\
\hline State FE & Yes & Yes & Yes & Yes \\
\hline Industry*Year FE & Yes & Yes & Yes & Yes \\
\hline Observations & 73,476 & 73,476 & 73,476 & 73,476 \\
\hline R-squared & 0.763 & 0.763 & 0.763 & 0.763 \\
\hline \multicolumn{5}{|c|}{ Panel C Management Forecasts-IV Second Stage } \\
\hline & (1) & $(2)$ & (3) & (4) \\
\hline & Freq_Long_Walk-up & Freq_Long_Walk-down & Freq_Short_Walk-up & Freq_Short_Walk-down \\
\hline \%Connect_Pred & $\begin{array}{c}0.458 \\
(2.65)^{* * *}\end{array}$ & $\begin{array}{l}-0.080 \\
(-0.46)\end{array}$ & $\begin{array}{l}\mathbf{0 . 0 5 0} \\
(0.30)\end{array}$ & $\begin{array}{c}0.398 \\
(2.28)^{* *}\end{array}$ \\
\hline Controls & Yes & Yes & Yes & Yes \\
\hline Firm FE & Yes & Yes & Yes & Yes \\
\hline State FE & Yes & Yes & Yes & Yes \\
\hline Industry*Year FE & Yes & Yes & Yes & Yes \\
\hline Observations & 73,476 & 73,476 & 73,476 & 73,476 \\
\hline R-squared & 0.087 & 0.142 & 0.065 & 0.127 \\
\hline
\end{tabular}


Table 5 Management Forecasts, Continued

Panel D Differences-in-Differences

(1)

Freq_Long_Walk-up

\begin{tabular}{|c|c|c|c|c|}
\hline Connect_Appointed $*$ Post & $\begin{array}{c}0.015 \\
(1.86)^{*}\end{array}$ & $\begin{array}{l}0.013 \\
(1.29)\end{array}$ & $\begin{array}{l}0.007 \\
(0.74)\end{array}$ & $\begin{array}{c}0.034 \\
(3.28)^{* * *}\end{array}$ \\
\hline \multirow[t]{2}{*}{ Post } & 0.002 & -0.005 & -0.001 & -0.001 \\
\hline & (1.04) & $(-2.26)^{* *}$ & $(-0.41)$ & $(-0.52)$ \\
\hline \multirow[t]{2}{*}{$K S$} & 0.001 & -0.002 & -0.002 & -0.002 \\
\hline & $(0.80)$ & $(-1.80)^{*}$ & $(-2.15)^{* *}$ & $(-2.36)^{* *}$ \\
\hline \multirow[t]{2}{*}{ Size } & 0.014 & 0.036 & 0.018 & 0.042 \\
\hline & $(4.66)^{* * *}$ & $(8.09)^{* * *}$ & $(4.36)^{* * *}$ & $(8.82)^{* * *}$ \\
\hline \multirow[t]{2}{*}{ Leverage } & 0.008 & -0.008 & 0.016 & 0.011 \\
\hline & $(0.74)$ & $(-0.61)$ & $(1.41)$ & $(0.76)$ \\
\hline \multirow{2}{*}{$R O A$} & -0.000 & -0.000 & 0.007 & -0.006 \\
\hline & $(-0.08)$ & $(-0.04)$ & $(1.83)^{*}$ & $(-0.92)$ \\
\hline \multirow[t]{2}{*}{ Loss } & -0.032 & -0.037 & -0.037 & -0.023 \\
\hline & $(-5.89) * * *$ & $(-5.64) * * *$ & $(-5.64) * * *$ & $(-3.12)^{* * *}$ \\
\hline \multirow[t]{2}{*}{ Analyst } & 0.020 & 0.037 & 0.015 & 0.024 \\
\hline & $(4.27)^{* * *}$ & $(6.45)^{* * *}$ & $(2.41)^{* *}$ & $(3.73)^{* * *}$ \\
\hline \multirow[t]{2}{*}{ Returns } & 0.011 & 0.025 & -0.010 & -0.025 \\
\hline & $(0.75)$ & $(1.36)$ & $(-0.54)$ & $(-1.24)$ \\
\hline \multirow[t]{2}{*}{ Financing } & 0.000 & -0.002 & 0.001 & -0.001 \\
\hline & $(0.49)$ & $(-2.11)^{* *}$ & $(0.92)$ & $(-1.09)$ \\
\hline \multirow[t]{2}{*}{ EPS_Decrease } & -0.014 & 0.025 & -0.026 & 0.023 \\
\hline & $(-3.43) * * *$ & $(5.30)^{* * *}$ & $(-5.59) * * *$ & $(4.49)^{* * *}$ \\
\hline \multirow[t]{2}{*}{ EPS_Change } & -0.014 & 0.026 & -0.020 & -0.008 \\
\hline & $(-2.68) * * *$ & $(4.22)^{* * *}$ & $(-3.18) * * *$ & $(-0.98)$ \\
\hline \multirow[t]{2}{*}{ EPS_Ratio } & 0.006 & -0.031 & 0.019 & 0.010 \\
\hline & $(0.91)$ & $(-4.07)^{* * *}$ & $(2.34)^{* *}$ & $(1.01)$ \\
\hline \multirow[t]{2}{*}{$\operatorname{Lag}(D V)$} & 0.259 & 0.252 & 0.148 & 0.351 \\
\hline & $(17.25)^{* * *}$ & $(14.58) * * *$ & $(10.47)^{* * *}$ & $(21.13)^{* * *}$ \\
\hline \multirow[t]{2}{*}{ Unemployment } & 0.671 & 0.535 & 0.260 & 1.286 \\
\hline & $(2.01)^{* *}$ & $(1.47)$ & $(0.71)$ & $(3.09)^{* * *}$ \\
\hline \multirow[t]{2}{*}{ GDP Growth } & 0.117 & -0.143 & 0.082 & -0.034 \\
\hline & (1.18) & $(-1.25)$ & $(0.74)$ & $(-0.26)$ \\
\hline Firm FE & Yes & Yes & Yes & Yes \\
\hline State FE & Yes & Yes & Yes & Yes \\
\hline Industry*Year FE & Yes & Yes & Yes & Yes \\
\hline Observations & 63,125 & 63,125 & 63,125 & 63,125 \\
\hline R-squared & 0.543 & 0.594 & 0.496 & 0.627 \\
\hline
\end{tabular}




\section{Table 6 Parallel Trend Tests}

Table 6 estimates the effect of connections on management forecasts in the years before and after new judge appointments to test the parallel trend assumption. The sample period is from 1996 to 2017. All variables are defined in Appendix A. Intercepts are included but unreported. $t$-statistics are presented below the coefficients in parentheses. $* * *, * *$, and * denote statistical significance (two-sided) at the $1 \%, 5 \%$, and $10 \%$ levels, respectively. Standard errors are corrected for heteroscedasticity and are clustered at the firm level.

(1) (2) (3) (4)

Freq_Long_Walk-up Freq_Long_Walk-down Freq_Short_Walk-up Freq_Short_Walk-down

\begin{tabular}{|c|c|c|c|c|}
\hline Connect_Appointed $*$ Before $(t=-2)$ & $\begin{array}{l}0.009 \\
(0.86)\end{array}$ & $\begin{array}{l}0.007 \\
(0.58)\end{array}$ & $\begin{array}{l}0.001 \\
(0.12)\end{array}$ & $\begin{array}{l}0.001 \\
(0.10)\end{array}$ \\
\hline \multirow[t]{2}{*}{ Connect_Appointed $*$ Before $(t=-1)$} & 0.012 & 0.004 & -0.003 & 0.015 \\
\hline & (1.04) & $(0.31)$ & $(-0.20)$ & (1.09) \\
\hline \multirow[t]{2}{*}{ Connect_Appointed $*$ Post $(t=1)$} & 0.026 & 0.013 & 0.001 & 0.032 \\
\hline & $(2.00)^{* *}$ & $(0.90)$ & $(0.04)$ & $(2.10)^{* *}$ \\
\hline \multirow[t]{2}{*}{ Connect_Appointed $*$ Post $(t=2)$} & 0.016 & 0.021 & 0.012 & 0.031 \\
\hline & $(1.27)$ & $(1.42)$ & $(0.81)$ & $(1.98)^{* *}$ \\
\hline \multirow[t]{2}{*}{ Connect_Appointed ${ }^{*}$ Post $(t=3)$} & 0.028 & 0.016 & 0.009 & 0.060 \\
\hline & $(2.05)^{* *}$ & (1.04) & $(0.55)$ & $(3.57)^{* * *}$ \\
\hline \multirow[t]{2}{*}{ Before $(t=-2)$} & -0.001 & 0.000 & -0.000 & -0.001 \\
\hline & $(-0.64)$ & $(0.18)$ & $(-0.06)$ & $(-0.33)$ \\
\hline \multirow{2}{*}{ Before $(t=-1)$} & 0.002 & -0.002 & 0.004 & 0.000 \\
\hline & $(1.00)$ & $(-0.58)$ & $(1.47)$ & $(0.09)$ \\
\hline \multirow{2}{*}{$\operatorname{Post}(t=1)$} & -0.001 & -0.008 & -0.000 & -0.000 \\
\hline & $(-0.28)$ & $(-2.70)^{* * *}$ & $(-0.02)$ & $(-0.11)$ \\
\hline \multirow[t]{2}{*}{ Post $(t=2)$} & 0.004 & -0.003 & 0.003 & -0.002 \\
\hline & (1.39) & $(-0.87)$ & $(0.85)$ & $(-0.49)$ \\
\hline \multirow[t]{2}{*}{ Post $(t=3)$} & 0.004 & -0.003 & -0.000 & -0.002 \\
\hline & (1.59) & $(-1.09)$ & $(-0.13)$ & $(-0.43)$ \\
\hline \multirow[t]{2}{*}{$K S$} & 0.001 & -0.002 & -0.002 & -0.002 \\
\hline & $(0.80)$ & $(-1.79)^{*}$ & $(-2.15)^{* *}$ & $(-2.35)^{* *}$ \\
\hline \multirow[t]{2}{*}{ Size } & 0.014 & 0.036 & 0.018 & 0.042 \\
\hline & $(4.67)^{* * *}$ & $(8.10)^{* * *}$ & $(4.36)^{* * *}$ & $(8.82)^{* * *}$ \\
\hline \multirow[t]{2}{*}{ Leverage } & 0.008 & -0.008 & 0.016 & 0.010 \\
\hline & $(0.73)$ & $(-0.62)$ & $(1.40)$ & $(0.73)$ \\
\hline \multirow[t]{2}{*}{$R O A$} & -0.000 & -0.000 & 0.007 & -0.006 \\
\hline & $(-0.09)$ & $(-0.03)$ & $(1.83)^{*}$ & $(-0.93)$ \\
\hline \multirow[t]{2}{*}{ Loss } & -0.032 & -0.037 & -0.037 & -0.023 \\
\hline & $(-5.88) * * *$ & $(-5.64) * * *$ & $(-5.64)^{* * *}$ & $(-3.12) * * *$ \\
\hline \multirow[t]{2}{*}{ Analyst } & 0.020 & 0.037 & 0.015 & 0.024 \\
\hline & $(4.26)^{* * *}$ & $(6.44)^{* * *}$ & $(2.41)^{* *}$ & $(3.72)^{* * *}$ \\
\hline \multirow[t]{2}{*}{ Returns } & 0.011 & 0.025 & -0.010 & -0.025 \\
\hline & $(0.75)$ & $(1.34)$ & $(-0.55)$ & $(-1.23)$ \\
\hline \multirow[t]{2}{*}{ Financing } & 0.000 & -0.002 & 0.001 & -0.001 \\
\hline & $(0.48)$ & $(-2.11)^{* *}$ & $(0.92)$ & $(-1.09)$ \\
\hline \multirow[t]{2}{*}{ EPS_Decrease } & -0.014 & 0.025 & -0.026 & 0.023 \\
\hline & $(-3.44)^{* * *}$ & $(5.30)^{* * *}$ & $(-5.59)^{* * *}$ & $(4.48)^{* * *}$ \\
\hline \multirow[t]{2}{*}{ EPS_Change } & -0.014 & 0.026 & -0.020 & -0.008 \\
\hline & $(-2.69)^{* * *}$ & $(4.22)^{* * *}$ & $(-3.19) * * *$ & $(-1.00)$ \\
\hline \multirow[t]{2}{*}{ EPS_Ratio } & 0.006 & -0.031 & 0.019 & 0.010 \\
\hline & $(0.91)$ & $(-4.06)^{* * *}$ & $(2.35)^{* *}$ & (1.00) \\
\hline \multirow[t]{2}{*}{$\operatorname{Lag}(D V)$} & 0.259 & 0.252 & 0.148 & 0.351 \\
\hline & $(17.24)^{* * *}$ & $(14.57)^{* * *}$ & $(10.47)^{* * *}$ & $(21.12)^{* * *}$ \\
\hline Unemployment & 0.668 & 0.537 & 0.259 & 1.282 \\
\hline & $(2.00)^{* *}$ & $(1.47)$ & $(0.70)$ & $(3.08)^{* * *}$ \\
\hline GDP Growth & 0.117 & -0.143 & 0.084 & -0.033 \\
\hline & (1.18) & $(-1.25)$ & $(0.76)$ & $(-0.25)$ \\
\hline Firm FE & Yes & Yes & Yes & Yes \\
\hline State FE & Yes & Yes & Yes & Yes \\
\hline Industry*Year FE & Yes & Yes & Yes & Yes \\
\hline Observations & 63,125 & 63,125 & 63,125 & 63,125 \\
\hline R-squared & 0.544 & 0.594 & 0.496 & 0.627 \\
\hline
\end{tabular}




\section{Table 7 Financial Misconduct}

Table 7 examines the effect of connections on financial misconduct using Instrumental Variable Regressions. Financial misconduct is measured using (1) the probability of SCAL litigation (Pr [Litigation]), (2) frequency of optimistic long-term forecasts (Freq_Long_Optimistic), (3) frequency of optimistic short-term forecasts (Freq_Short_Optimistic), and (4) frequency of SEC enforcement actions and/or financial restatements (Misreporting). The sample period is from 1996 to 2017. All variables are defined in Appendix A. Intercepts are included but unreported. $t$-statistics are presented below the coefficients in parentheses. ***,**, and * denote statistical significance (two-sided) at the 1\%,5\%, and 10\% levels, respectively. Standard errors are corrected for heteroscedasticity and are clustered at the firm level.

\begin{tabular}{|c|c|c|c|c|}
\hline \multicolumn{5}{|c|}{ Panel A Financial Misconduct- IV First Stage } \\
\hline & $(1)$ & $(2)$ & (3) & $(4)$ \\
\hline & \% Connect (for Pr[Litigation]) & \%Connect (for Freq_Long_Optimistic) & \%Connect(for Freq_Short_Optimistic) & \%Connect (for Misreporting) \\
\hline \%Connect_Appointed & $\begin{array}{c}0.725 \\
(30.38)^{* * *}\end{array}$ & $\begin{array}{c}0.725 \\
(30.38) * * *\end{array}$ & $\begin{array}{c}0.725 \\
(30.38) * * *\end{array}$ & $\begin{array}{c}0.725 \\
(30.38)^{* * * *}\end{array}$ \\
\hline Controls & Yes & Yes & Yes & Yes \\
\hline Firm FE & Yes & Yes & Yes & Yes \\
\hline Industry*Year FE & Yes & Yes & Yes & Yes \\
\hline Headquarter FE & Yes & Yes & Yes & Yes \\
\hline Observations & 73,476 & 73,476 & 73,476 & 73,476 \\
\hline R-squared & 0.763 & 0.763 & 0.763 & 0.763 \\
\hline \multicolumn{5}{|c|}{ Panel B Financial Misconduct- IV Second Stage } \\
\hline & (1) & (2) & (3) & (4) \\
\hline & $\operatorname{Pr}[$ Litigation] & Freq_Long_Optimistic & Freq_Short_Optimistic & Misreporting \\
\hline \%Connect_Pred & $\begin{array}{l}-0.107 \\
(-1.25)\end{array}$ & $\begin{array}{l}0.175 \\
(0.82)\end{array}$ & $\begin{array}{l}-0.017 \\
(-0.11)\end{array}$ & $\begin{array}{l}0.033 \\
(0.25)\end{array}$ \\
\hline Controls & Yes & Yes & Yes & Yes \\
\hline Firm FE & Yes & Yes & Yes & Yes \\
\hline Industry*Year FE & Yes & Yes & Yes & Yes \\
\hline Headquarter FE & Yes & Yes & Yes & Yes \\
\hline Observations & 73,476 & 73,476 & 73,476 & 73,476 \\
\hline R-squared & 0.023 & 0.064 & 0.043 & 0.201 \\
\hline
\end{tabular}

